Portland State University

PDXScholar

Environmental Science and Management

Faculty Publications and Presentations

\title{
Forest Restoration in a Mixed-Ownership Landscape under Climate Change
}

\author{
Catherine Ravenscroft \\ University of Wisconson, Madison \\ Robert M. Scheller \\ Portland State University \\ David J. Mladenoff \\ University of Wisconsin, Madison \\ Mark A. White \\ The Nature Conservancy
}

Follow this and additional works at: https://pdxscholar.library.pdx.edu/esm_fac

Part of the Environmental Indicators and Impact Assessment Commons, Forest Management Commons, and the Natural Resources and Conservation Commons

Let us know how access to this document benefits you.

\section{Citation Details}

Ravencroft, C., Scheller, R. M., Mladenoff, D. J., \& White, M. A. (2010). Forest restoration in a mixedownership landscape under climate change. Ecological Applications, 20(2), 327-346.

This Article is brought to you for free and open access. It has been accepted for inclusion in Environmental Science and Management Faculty Publications and Presentations by an authorized administrator of PDXScholar. Please contact us if we can make this document more accessible: pdxscholar@pdx.edu. 


\title{
Forest restoration in a mixed-ownership landscape under climate change
}

\author{
Catherine Ravenscroft, ${ }^{1,3}$ Robert M. Scheller,${ }^{1,4}$ David J. Mladenoff, ${ }^{1}$ and Mark A. White ${ }^{2}$ \\ ${ }^{1}$ Department of Forest and Wildlife Ecology, University of Wisconsin, 1630 Linden Drive, Madison, Wisconsin 53706 USA \\ ${ }^{2}$ The Nature Conservancy in Minnesota, 394 Lake Avenue S., Duluth, Minnesota 55802 USA
}

\begin{abstract}
The extent to which current landscapes deviate from the historical range of natural variability (RNV) is a common means of defining and ranking regional conservation targets. However, climate-induced shifts in forest composition may render obsolete restoration strategies and conservation targets based on historic climate conditions and disturbance regimes. We used a spatially explicit forest ecosystem model, LANDIS-II, to simulate the interaction of climate change and forest management in northeastern Minnesota, USA. We assessed the relevance of restoration strategies and conservation targets based on the RNV in the context of future climate change. Three climate scenarios (no climate change, low emissions, and high emissions) were simulated with three forest management scenarios: no harvest, current management, and a restoration-based approach where harvest activity mimicked the frequency, severity, and size distribution of historic natural disturbance regimes. Under climate change there was a trend toward homogenization of forest conditions due to the widespread expansion of systems dominated by maple (Acer spp.). White spruce (Picea glauca), balsam fir (Abies balsamea), and paper birch (Betula papyrifera) were extirpated from the landscape irrespective of management activity; additional losses of black spruce $(P$. mariana), red pine (Pinus resinosa), and jack pine ( . banksiana) were projected in the highemissions scenario. In the restoration management scenario, retention and conversion to white pine $(P$. strobus) restricted maple expansion. But, widespread forest loss in the restoration scenario under high-emissions projections illustrates the potential pitfalls of implementing an RNV management approach in a system that is not compositionally similar to the historic reference condition. Given the uncertainty associated with climate change, ensuring a diversity of species and conditions within forested landscapes may be the most effective means of ensuring the future resistance of ecosystems to climate-induced declines in productivity.
\end{abstract}

Key words: climate change; desired conditions; forest ecosystem model, LANDIS-II; forest management; historical variability; Minnesota (USA); range of natural variability (RNV); restoration; species migration.

\section{INTRODUCTION}

Historic landscape reconstructions are often used to define a reference condition from which to assess the magnitude of change under intensive human influence (Landres et al. 1999). The extent to which the current landscape deviates from the historical ("natural") range of variability (RNV) is a common means of defining and ranking regional conservation targets (Landres et al. 1999, Swetnam et al. 1999). However, climate-induced shifts in forest composition may render obsolete restoration strategies and conservation targets based on historic climate conditions and disturbance regimes. The relevance of the RNV to any future period is based

Manuscript received 12 September 2008; revised 28 April 2009; accepted 29 May 2009. Corresponding Editor: D. McKenzie.

${ }^{3}$ Present address: Department of Biology, Syracuse University, 130 College Place, Syracuse, New York 13244 USA. E-mail: chravens@syr.edu

${ }^{4}$ Present address: Conservation Biology Institute, $136 \mathrm{SW}$ Washington, Suite 202, Corvallis, Oregon 97333 USA. on the assumption of climate stability throughout the two periods (Millar and Woolfenden 1999). If climate changes as projected, this assumption will be violated, leading to potential inaccuracies in applied management (Millar and Woolfenden 1999) and unrealistic conservation targets.

Climate-induced compositional shifts are predicted to be most rapid and evident at abrupt transitions between current biomes (Neilson 1993, Noble 1993, Pitelka 1997, Allen and Breshears 1998). Forests in northeastern Minnesota, USA, encompass the temperate/boreal forest transition, which is projected to be particularly sensitive to climate change (Pastor and Post 1988). Results from an equilibrium biogeography model (Mapped Atmosphere-Plant-Soil System [MAPSS]; Neilson 1995) and a dynamic global vegetation model (MC1) suggest a loss of conifer forest in northeastern Minnesota with a corresponding increase in mixed temperate forest under climate change (Bachelet et al. 2001).

Niche-based projections of eastern U.S. tree species range shifts in response to climate change predict a 
substantial loss of suitable climatic envelopes for spruce (Picea spp.), balsam fir (Abies balsamea), aspen (Populus spp.), and paper birch (Betula papyrifera) and expansion of suitable niche space for maple (Acer spp.), oak (Quercus spp.), and hickory (Carya spp.) in northeastern Minnesota (Iverson and Prasad 1998, 2001, Prasad et al. 2006, Schwartz et al. 2006). Similar shifts were predicted in the mixed hardwood to conifer transition in northern Europe using a mechanistic bioclimatic model (Sykes and Prentice 1996). Niche-based statistical models use environmental parameters to estimate a species climatic envelope. An underlying assumption is that this niche space will be maintained under climate change. In contrast, mechanistic bioclimatic models offer predictions of species range shifts based on species physiological tolerance to environmental factors and assume that tolerance limits will be unaltered under climate change.

Species have individualistic responses to climate as well as migration rates, which may result in novel or disparate species assemblages in future climates (Hobbs et al. 2006, Williams and Jackson 2007). Shifts in the realized climatic niche between native and nonnative ranges of invasive species highlight the importance of biotic drivers as determinants of species distributions (Broennimann et al. 2007). For example, release from biotic constraints due to the absence of competitors, herbivores, or pathogens following range expansion under climate change could alter a species realized niche. On a longer timescale, adaptive evolution in response to climate change (Bradshaw and Holzapfel 2006) could alter a species fundamental niche space directly; or indirectly if interspecific dynamics were modified as a result.

Species characteristics such as seed dispersal limitation (Davis 1989) and regional niche variation (Hampe 2004, Hampe and Petit 2005, Murphy and Lovett-Doust 2007) combined with fragmentation (Scheller and Mladenoff 2008) and other disturbance processes (Scheller and Mladenoff 2005) will likely affect the response of species to climate change. Furthermore, climate change could alter ecosystem process rates such as productivity, decomposition, and biomass accumulation, which could influence competitive dynamics (Saxe et al. 2001). Modified disturbance regimes including insect and pathogen outbreaks, fire, and drought could influence or overwhelm direct effects of climate change on ecosystem stability (Overpeck et al. 1990, Dale et al. 2001).

The spatial configuration of forest ecosystems will be an important determinant of forest response to climate change (With 2004). Migration rates may be substantially reduced due to habitat loss and fragmentation (Collingham and Huntley 2000) and will vary among species with alternative reproductive strategies (Malanson and Cairns 1997). The interaction of habitat suitability and the rate of expected climate change threatens population survival and mobility (Davis and Shaw 2001) as migration rates may be insufficient if climate changes as rapidly as projected (McLachlan et al. 2005, Scheller and Mladenoff 2008).

Results from broadscale projections of species and community response to climate change substantiate the need to integrate the threat of climate change into conservation strategies. But they offer little insight regarding the relative efficacy of alternative management strategies to mitigate climatic-induced forest compositional change because management is not explicitly included. Forest management activity alters patterns of community composition and physiognomy at landscape scales and has the potential to either exacerbate or reduce the effects of climate change (Franklin et al. 1991, Noss 2001, Scheller and Mladenoff 2005). For example, species establishment is considered to be particularly sensitive to climate change, and intensive management during the regeneration phase could maintain species on the landscape even if the climate is no longer optimal (Spittlehouse and Stewart 2003). Conversely, management practices that synchronize forest composition and physiognomy could make the landscape particularly vulnerable to climate-induced shifts in composition (Millar et al. 2007).

An adaptive approach to management, in which alternative management techniques and restoration targets are adjusted iteratively, may be the most effective strategy, given the uncertainties of climate change impacts (Dale et al. 2001, Hannah et al. 2002, Spittlehouse 2005).

Conservation efforts and restoration strategies must continue to abate current threats such as incompatible forest management and development while incorporating the potential effects of climate change (Hannah et al. 2002). Defining realistic conservation targets, and implementing appropriate management strategies to achieve them, require additional tools that characterize the nature of these interactions.

Models that couple spatially interactive processes with local population dynamics are particularly well-suited to explore the feedbacks between climate change and a suite of broadscale processes that control extinction risk and community stability. Simulations of forest response to climate change using the landscape simulation model LANDIS demonstrate the utility of integrating climate change scenarios and disturbance dynamics into spatially explicit projections of forest composition and productivity (He et al. 1999b, Scheller and Mladenoff 2005). Disturbance processes such as harvest and windthrow can affect both the magnitude of compositional change and the detrimental effects of seed dispersal limitation (Scheller and Mladenoff 2005); dispersal limitation is particularly problematic in fragmented landscapes (Scheller and Mladenoff 2008).

We model the interaction of climate change and forest management in forests of northeastern Minnesota, to evaluate the extent to which climate-induced shifts in forest composition can be mitigated through management activity and to assess the applicability of RNV- 


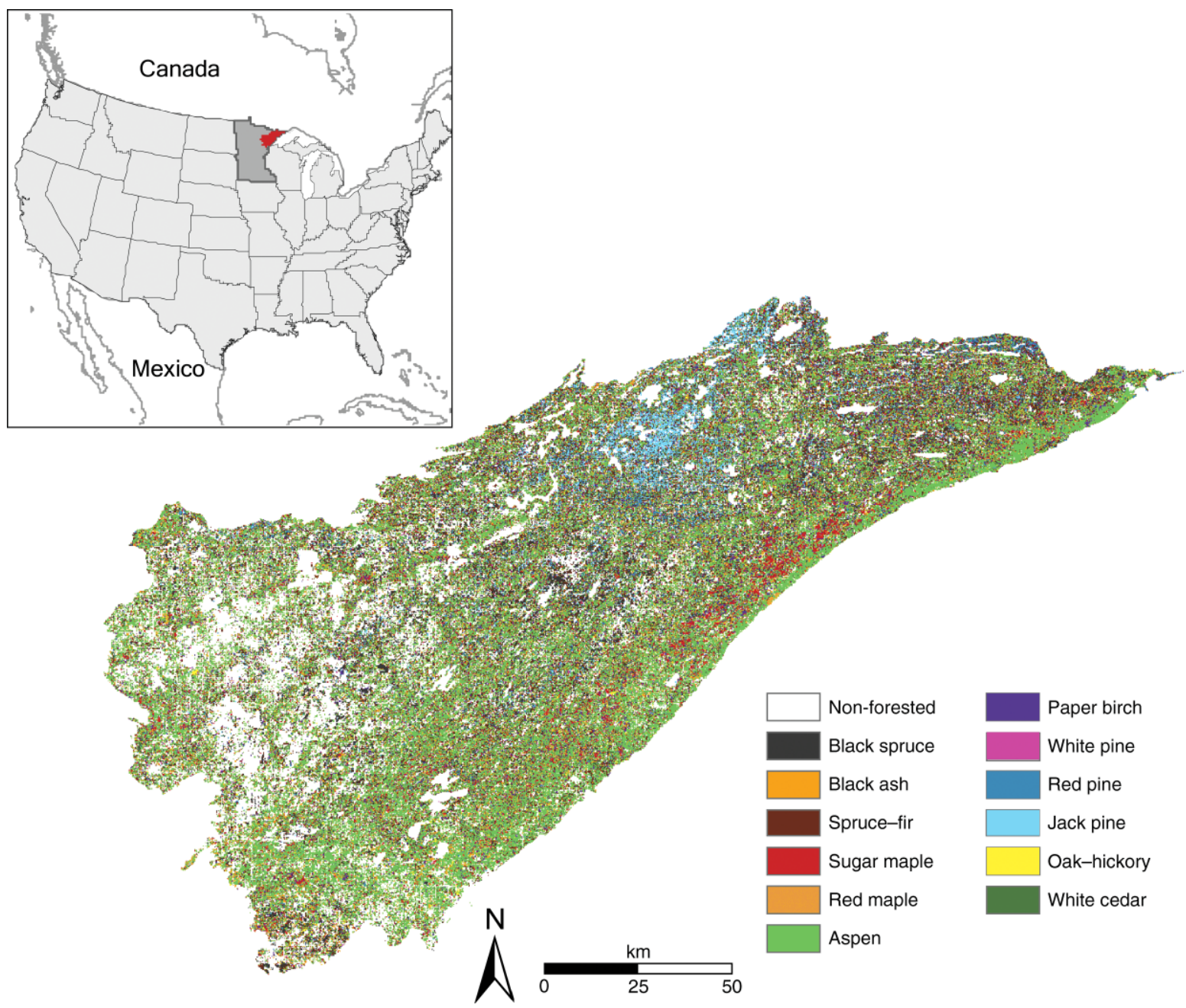

FIG. 1. Map of study area and dominant cover types estimated from a 1995 satellite vegetation classification (Wolter and White 2002). The study region (shown in red in inset) is located in northeastern Minnesota, USA.

based conservation approaches in the context of future climate change. The specific questions addressed are the following. (1) How will forest species composition shift under different climate change scenarios? (2) Do alternative forest management strategies change trajectories of climate-induced shifts in species composition? (3) Are conservation targets and restoration strategies based on the RNV relevant given the magnitude of compositional shifts predicted under future climate change?

\section{Study Region}

The study landscape in northeastern Minnesota (USA) comprises $2 \times 10^{6}$ ha in the transition zone between temperate and boreal forests and encompasses much of the regional variability in physical and edaphic environments. Aspen (Populus tremuloides) and northern hardwood-conifer forests dominated by sugar maple (Acer saccharum), with yellow birch (Betula alleghaniensis), red maple (Acer rubrum), and basswood (Tilia americana), predominate in mesic uplands and are interspersed with productive lowland forest of black ash (Fraxinus nigra) and white cedar (Thuja occidentalis), and unproductive lowland forest of black spruce (Picea mariana; see Fig. 1). Forests dominated by red, white, and jack pine (Pinus resinosa, P. strobus, $P$. banksiana) constitute a small proportion of the landscape (Fig. 1). Fire-dependent jack pine is prevalent on well-drained, coarse-textured, and thin soils over bedrock. Red pine is more common on slightly less xeric sites such as sandy moraines. White pine, the least specialized of the pine species, occupies a wider range of sites and drainage conditions.

This forest landscape is largely unfragmented, but management and conservation are challenged by mixed ownership: $67 \%$ of the landscape is under public ownership; $28 \%$ is in private nonindustrial holdings; and $3.3 \%$ of the landscape is under private industrial ownership (Fig. 2). There is substantial variation in forest management practices across the region due to differences in management objectives among landown- 


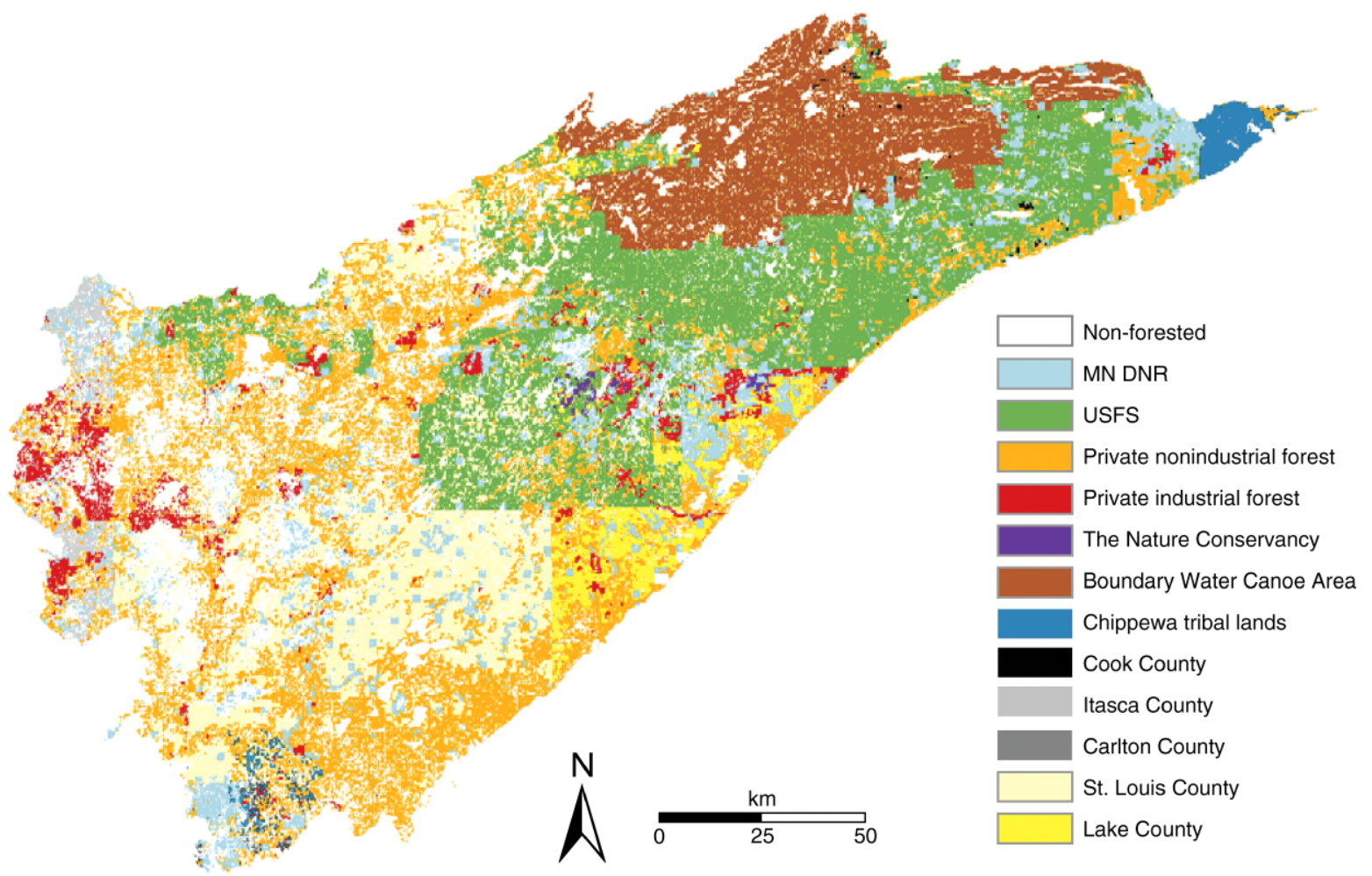

FIG. 2. Map of ownership types that represent separate management units in current management scenarios. Carlton, Itasca, and Cook Counties, and Chippewa tribal lands lacked detailed management information and were grouped with larger management units based on location and known associations between management agencies (Table 4). Key to abbreviations: MN DNR, Minnesota Department of Natural Resources; USFS, United States Forest Service.

ers. For example, intensively managed private industrial forests contrast with the Boundary Waters Canoe Area (BWCA), a wilderness area within the Superior National Forest that is not harvested (Hall et al. 1991).

A reference condition based on estimates of historic forest composition (middle to late 1800s) derived from an analysis of U.S. General Land Office (GLO) bearing tree data (White 2001a,b) forms the basis for regional forest-level conservation targets. Current species composition, age class distributions, and landscape structure deviate significantly from the reference condition (Frelich 1999, 2000, White and Host 2000, Friedman and Reich 2005). Land use change and alteration of the natural disturbance regime combined with intensive management practices following Euro-American settlement in the late 19th to early 20th centuries have reduced the abundance of old-growth conifer and hardwoods, with a concomitant increase in the proportion of early successional, second-growth forests (Friedman et al. 2001, Friedman and Reich 2005), similar to trends visible across the region (Schulte et al. 2007). Outside of wilderness areas timber harvest has replaced fire and windthrow as the dominant disturbance. Fire suppression and intensive harvesting have been suggested as the primary reasons for a substantial loss in red pine, white pine, and jack pine across the entire region (Heinselman 1973, 1981, 1996, Scheller et al. 2005).
A RNV-based approach to management seeks to develop a landscape more representative of reference conditions by restoring natural disturbance regimes (Baker 1992, 1994) or implementing management options that mimic these processes (Bergeron and Harvey 1997, Aber et al. 2000, Kuuluvainen 2002, Jogiste et al. 2007). Successful strategies reduce compound threats to ecosystem stability with the ultimate goal of restoring or maintaining species and communities to reflect historic proportions. The spatial distribution of the seven ecological land units derived from associations between sample vegetation data and soil, landform, and climate patterns (White and Host 2000) provides a useful context to evaluate the ecological potential of RNVbased restoration targets in the study region (Fig. 3). Regional restoration priorities include: (1) increasing the abundance of red and white pine in mesic and dry-mesic white pine-red pine land units, (2) increasing jack pine in dry-mesic jack pine-black spruce land units, (3) increasing the proportion of mesic birch-aspen-spruce-fir, boreal hardwood-conifer, and hardwood-conifer land units in later vegetation growth stages.

\section{Methods \\ Model description}

We simulated the interaction of climate change and forest management in northeastern Minnesota using 


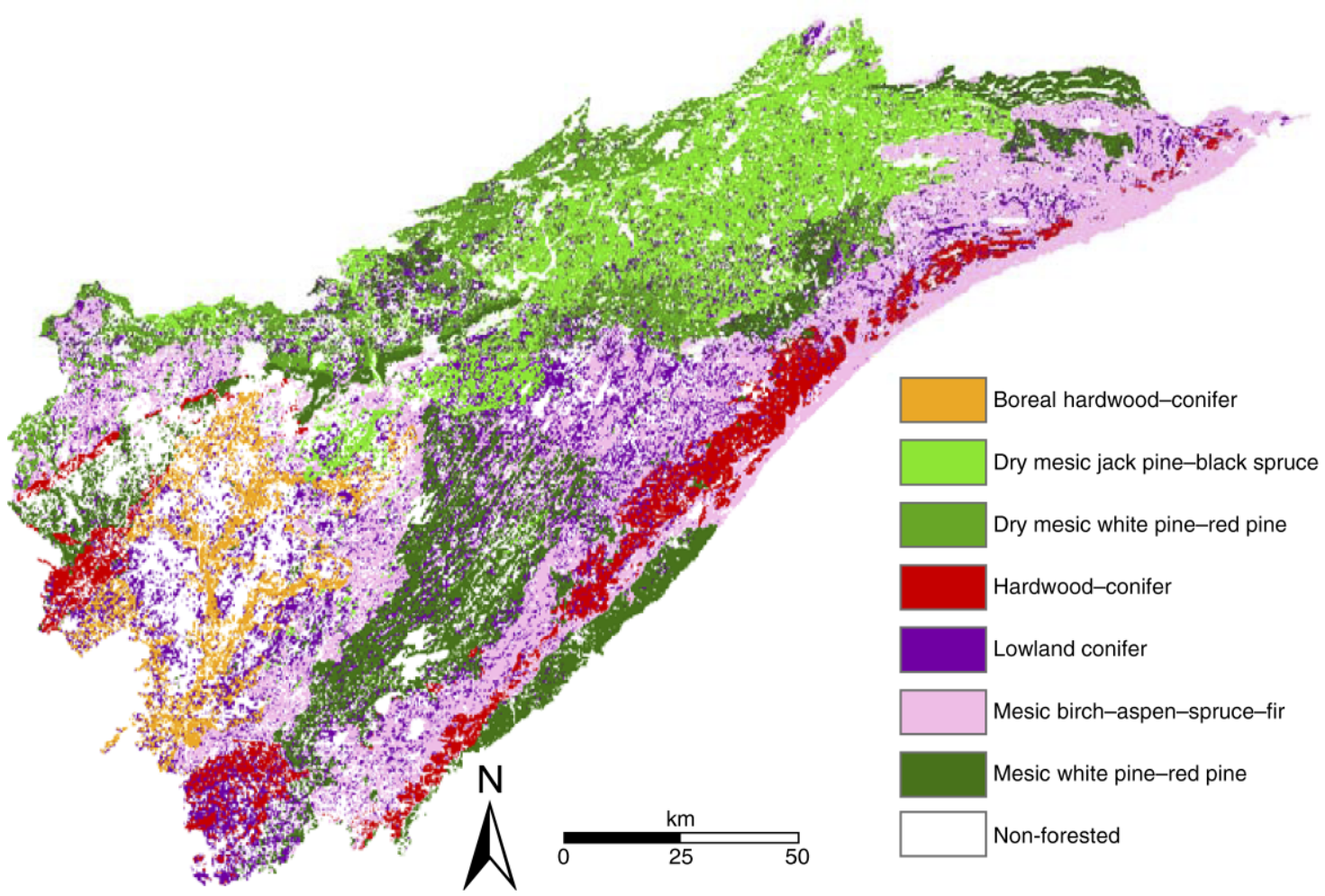

FIG. 3. Map of the spatial distribution of seven ecological land units derived from associations between sample vegetation data and soil, landform, and climate patterns (White and Host 2000). Each ecological land unit is a separate management unit in restoration management scenarios.

LANDIS-II. LANDIS is a spatially explicit, interactive landscape simulation model that simulates successional dynamics, windthrow, harvest, fire, and seed dispersal (Mladenoff et al. 1996, He et al. 1999a, Mladenoff and He 1999). The LANDIS-II enhancements incorporate ecosystem processes such as biomass accumulation and decomposition (Scheller and Mladenoff 2004, Scheller et al. 2007). The landscape is represented as a grid of interacting cells; each cell exists within an ecoregion assumed to have homogeneous climate and soil properties. Multiple species-age cohorts can exist in a given cell, and each cell contains relevant species biomass and age information. Mortality of cohorts can occur as a result of disturbance events such as wind, harvest, and fire; regimes can be simulated with varying intensity and frequency across the landscape. A cell can serve as a seed source if occupied by mature-age cohorts. The probability of seed dispersal declines exponentially with distance from the source cell. Ninety-five percent of the probability is assigned to the effective dispersal distance of a species and 5\% is assigned to the maximum dispersal distance of a species (cf. Clark et al. 1998, Ward et al. 2004).

\section{Experimental design}

We simulated nine scenarios of climate change and forest management for 200 years, beginning in the year
1995. All scenarios were simulated at five-year time steps with a cell size of $142.5 \mathrm{~m} \times 142.5 \mathrm{~m}$. The temporal resolution of LANDIS-II is flexible and user specified (Scheller et al. 2007). A five-year time step incorporated climate variability at a reasonable temporal resolution while also allowing a simulation length of 200 years as computational load increases with the number of time steps. The first climate scenario assumed continuation of current climate conditions. Data from the third Hadley Climate Centre general circulation model (HADCM3) under high (A2) and low (B2) emissions projections were used to create two climate change scenarios. Emissions scenarios were selected to encapsulate the range of uncertainty in emissions projections. HADCM3 was selected as monthly temperature and precipitation output from the control model run for the time period 1971-2000 was closer to Parameter-elevation Regressions on Independent Slopes Model (hereafter, PRISM) 30-year normals (Daly et al. 1994) than output from the National Centre for Atmospheric Research (NCARPCM). Climate scenarios were simulated with three different forest management scenarios: no harvest, continuation of current management, and a restoration-based management approach.

We simulated 24 species, 20 of which are common in the region (Table 1). We included four species that are currently uncommon or not present in the study area: 
TABLE 1. Life history attributes, percentage foliar nitrogen, and maximum leaf mass area (LMA) for 20 tree species simulated in northeastern Minnesota, USA.

\begin{tabular}{|c|c|c|c|c|}
\hline Species & $\begin{array}{l}\text { Max. age } \\
(\mathrm{yr})\end{array}$ & $\begin{array}{l}\text { Min. seeding } \\
\text { age }(\mathrm{yr})\end{array}$ & Shade tolerance $\dagger$ & $\begin{array}{l}\text { Effective seeding } \\
\text { distance }(m)\end{array}$ \\
\hline American elm (Ulmus americana) & 75 & 20 & 4 & 90 \\
\hline Aspen (Populus tremuloides) & 90 & 15 & 1 & 500 \\
\hline Balsam fir (Abies balsamea) & $100 \dagger$ & 25 & 5 & 30 \\
\hline Basswood (Tilia americana) & 250 & 15 & 4 & 75 \\
\hline Big-toothed Aspen (Populus grandifolia) & 90 & 20 & 1 & 500 \\
\hline Bitternut hickory (Carya cordiformis) & 300 & 30 & 3 & 30 \\
\hline Black ash (Fraxinus nigra) & 150 & 30 & 1 & 200 \\
\hline Black cherry (Prunus serotina) & 200 & 20 & 3 & 30 \\
\hline Black spruce (Picea mariana) & 200 & 30 & 4 & 79 \\
\hline Bur oak (Quercus macrocarpa) & 300 & 30 & 2 & 40 \\
\hline Green ash (Fraxinus pennsylvanica) & 150 & 30 & 2 & 100 \\
\hline Jack pine (Pinus banksiana) & 120 & 10 & 1 & 30 \\
\hline Red oak (Quercus rubra) & 250 & 25 & 2 & 40 \\
\hline Pin oak (Quercus ellipsoidalis) & 200 & 35 & 2 & 40 \\
\hline Paper birch (Betula papyrifera) & 100 & 20 & 2 & 200 \\
\hline Red maple (Acer rubrum) & 150 & 10 & 4 & 100 \\
\hline Red pine (Pinus resinosa) & 250 & 15 & 2 & 100 \\
\hline Sugar maple (Acer saccharum) & 250 & 40 & 5 & 100 \\
\hline White ash (Fraxinus americana) & 200 & 30 & 4 & 70 \\
\hline White cedar (Thuja occidentalis) & 350 & 30 & 2 & 45 \\
\hline White oak (Quercus alba) & 400 & 40 & 3 & 40 \\
\hline White pine (Pinus strobus) & 350 & 15 & 3 & 100 \\
\hline White spruce (Picea glauca) & 120 & 25 & 3 & 30 \\
\hline Yellow birch (Betula alleghaniensis) & 300 & 40 & 4 & 100 \\
\hline
\end{tabular}

Note: Sources are indicated by superscripts: (1) Fownes 1985, (2) Jurik 1986, (3) Blinn and Buckner 1989, (4) Reich et al. 1995, (5) Bolster 1996, (6) Martin and Aber 1997, (7) Green 1998, (8) Smith and Martin 2001, (9) Green et al. 2003, (10) Bolstad et al. 2004, (11) Scheller and Mladenoff 2004, (12) Lee et al. 2005, (13) Royer et al. 2005, (14) Scheller and Mladenoff 2005.

$\uparrow$ Shade tolerance is an ordinal scale: 1 (least shade tolerant) to 5 (most tolerant) (Baker 1949).

\$ Maximum age of balsam fir reduced from 200 years to account for spruce budworm incidence.

$\S$ Estimated from white ash (Fraxinus americana).

ฯ Estimated from white spruce (Picea glauca).

bitternut hickory (Carya cordiformis), white ash (Fraxinus americana), northern pin oak (Quercus ellipsoidalis), and white oak (Quercus alba). These species are likely to expand into the region within 100 years under climate change based on two criteria: effective dispersal distance and distance between the southern boundary of the study area and the northern range limit of a species estimated from a digitized version of range maps originally compiled by Little (Little 1971, Prasad and Iverson 2003). We simulated northern range expansion by planting these four species in $1 \%$ of the southern portion of the study area for 10 years beginning in 2065 . The main purpose of the planting routine was to establish these species in the study region. Planting was restricted to a 10-year period so we could assess the natural rate of expansion of these species once established in the region.

\section{Initial forest composition and age input map}

An initial vegetation map with species-age cohort information was compiled from numerous sources. A Landsat forest classification was used to generate a map of dominant cover type (Fig. 1; Wolter et al. 1995, Wolter and White 2002). Recent age classes, up to 15 years, were assigned using change transition maps where conversions from forested to non-forested are identified based on differences in pixel reflectance of Landsat satellite data, available in sequential five-year intervals from 1986 to 2001 (Wolter and White 2002). Data from the Minnesota Department of Natural Resources (DNR) common stand inventory (CSI) of DNR, County and Federal lands for the Drift and Lake Plains and Northern Superior Uplands, were used to assign ages for stands older than 15 years. CSI data were only used if the main cover type in the inventory matched that of the Landsat classification (18\% of study region). For the remaining $78 \%$ of the study region, ages were assigned from age class distributions calculated for each main cover type using U.S. Forest Service Forest Inventory and Analysis (FIA) data, following He et al. [1998]. FIA data were also used to assign secondary and subcanopy species-age cohorts based on dominant cover type (He et al. 1998).

\section{Climate data}

For our control climate scenario, we compiled the mean and standard deviation of temperature and precipitation data from PRISM 30-year (1971-2000) normals, available at 4-km resolution (Daly et al. 1994). Monthly temperature and precipitation projections from the HADCM3 under IPCC high (A2) and low (B2) emissions scenarios, available at one-year time steps from 1995 to 2095, were used for the two climate change scenarios (Fig. 4). In the last 100 years of the 
TABLE 1. Extended.

\begin{tabular}{rlc}
\hline \hline $\begin{array}{c}\text { Max. seeding } \\
\text { distance }(\mathrm{m})\end{array}$ & \multicolumn{1}{c}{$\begin{array}{c}\text { Foliar } \\
\text { nitrogen }(\%)\end{array}$} & Max. LMA $\left(\mathrm{g} / \mathrm{m}^{2}\right)$ \\
\hline 400 & $2.00^{(11,13)}$ & $62^{(13)}$ \\
1000 & $2.50^{(14)}$ & $91^{(4,10,13)}$ \\
160 & $1.56^{(14)}$ & $204^{(14)}$ \\
150 & $2.40^{(1,5,6,8,13)}$ & $57^{(10,13)}$ \\
1000 & $2.30^{(5,13)}$ & $86^{(2,13)}$ \\
1000 & $2.30^{(14)}$ & $111^{(14)}$ \\
2000 & $2.11^{(3)}$ & $76 \S^{(14)}$ \\
3000 & $2.70^{(14)}$ & $101^{(14)}$ \\
158 & $1.21^{(4)}$ & $286^{\bullet}$ \\
1000 & $2.30^{(14)}$ & $88^{(14)}$ \\
300 & $2.13^{(3)}$ & $76^{\dagger}$ \\
100 & $1.24^{(4)}$ & $244^{(4,7)}$ \\
1000 & $2.18^{(1,4-5,6,8,10,12)}$ & $93^{(1-2,4,8,12-13)}$ \\
1000 & $2.30^{(14)}$ & $54^{(14)}$ \\
5000 & $2.30^{(14)}$ & $74^{(2,8,13)}$ \\
1000 & $1.75^{(1,4-6,8,10,12-13)}$ & $62^{(2,4,8,12-13)}$ \\
275 & $1.35^{(4-7)}$ & $250^{(4)}$ \\
200 & $1.86^{(1,4,6-8,10,13)}$ & $60^{(2,4,10,13)}$ \\
200 & $2.10^{(14)}$ & $76^{(14)}$ \\
60 & $1.30^{(14)}$ & $222^{(14)}$ \\
1000 & $2.50^{(14)}$ & $88^{(14)}$ \\
250 & $1.70^{(11)}$ & $175^{(11)}$ \\
200 & $1.34^{(11)}$ & $286^{(11)}$ \\
400 & $2.40^{(14)}$ & $66^{(14)}$ \\
\hline
\end{tabular}

simulation, mean temperature and precipitation values were held at the 10-year (2090-2100) average. In control climate scenarios and in the last 100 years of climate change scenarios, climate variability was incorporated via the standard deviation of temperature and precipitation. The A2 emissions scenario is the most extreme, with mean summer temperature in northeastern Minnesota projected to increase $6.9^{\circ} \mathrm{C}$ by 2100 (Fig. 4). The B2 emissions scenario was selected to represent the lower range of emissions scenarios with a projected increase in mean summer temperature of $3.7^{\circ} \mathrm{C}$ by 2100 (Fig. 4). There are no substantial changes in total precipitation projected in either scenario (Fig. 4). However, there are differences in seasonality. In particular, a greater proportion of precipitation falls as rain instead of snow. The influence of higher temperatures on the timing and duration of snowmelt is not considered in this study.

Climate change scenarios used the PRISM 30-year normals for the year 1995 and a five-year mean of the HADCM3 data for each subsequent five-year time step (e.g., climate at 2020 was calculated as the mean of years 2018-2022). In order to correct for global circulation model (GCM) projection error (deviation between observed and predicted values for current climate; Jenkins et al. 2000), temperature, precipitation, and solar surface irradiance were calculated as the predicted change from 1995 using a standard delta method. HADCM3 data, output at a resolution of $2.5^{\circ}$ latitude and $3.75^{\circ}$ longitude, was downscaled to $4 \mathrm{~km}$ resolution by adding projected changes to maps of PRISM normals.
Species establishment and growth

The study area was divided into 26 ecoregions based on STATSGO (STATSGO 1994) map unit identifiers (MUIDS; median size 61882 ha, range from 1314 ha to 310000 ha). Mean soil carbon, field capacity, and wilting point for each ecoregion were derived from the STATSGO database (Saxton et al. 1986, STATSGO 1994). Monthly temperature and precipitation data were averaged for each ecoregion. As a requisite model with linked disturbance, succession, and soil dynamics is not currently available, we assumed that soil water-holding capacity, carbon, and nitrogen were constant over time. Soil carbon and nitrogen are significantly less variable over time relative to forest management (Johnson and Curtis 2001), the dominant disturbance in the landscape.

Species probability of establishment and maximum net primary productivity are required model inputs that vary spatially due to ecoregional variation in soils and climate, and temporally due to interannual climatic variation and climate change. Species establishment at a given site is dependent on light conditions, availability of propagules, and the establishment probability $\left(P_{\text {est }}\right)$, which is based on species characteristics and the environmental attributes of the ecoregion, including soil
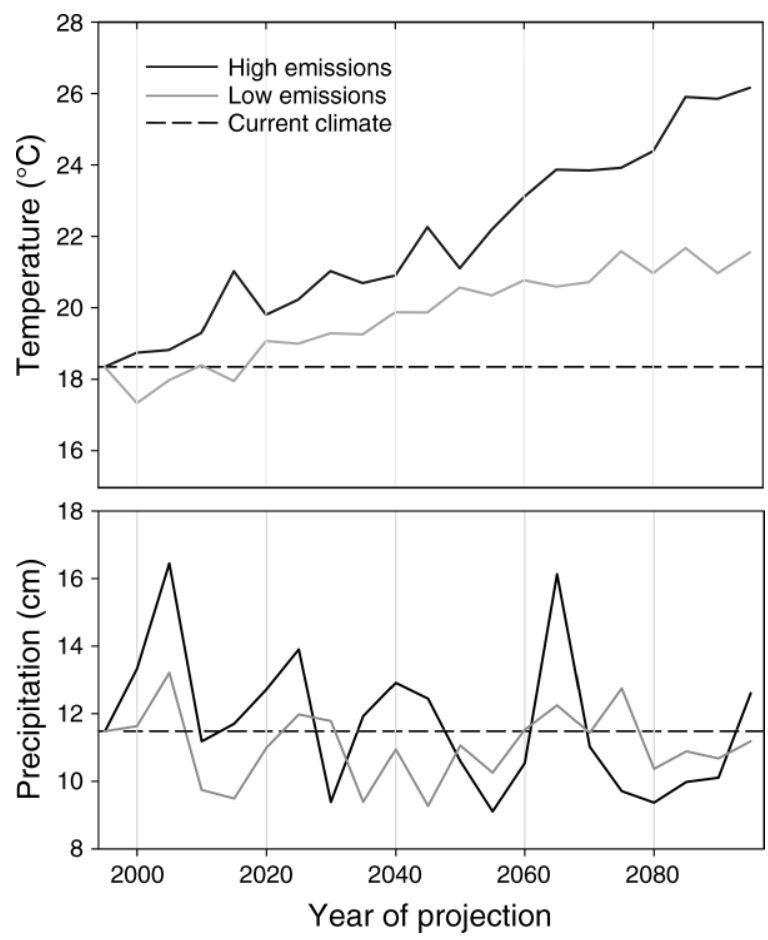

FIG. 4. Mean July temperature and annual total precipitation projections for 1995-2095 based on data from the third Hadley Climate Centre general circulation model (HADCM3) under low (B2) and high (A2) emissions projections. The PRISM 30-year average (1971-2000; dashed black line) was used for year 1995 in all climate scenarios. In climate change scenarios, temperature and precipitation were calculated as the predicted change from 1995 at a five-year time step (e.g., climate at 2020 was calculated as the mean of years 2018-2022). 
TABLE 2. Harvest prescriptions for the current management scenario with ownership-specific rotation periods for even-aged management and entry intervals for uneven-aged management.

\begin{tabular}{|c|c|c|c|c|c|c|c|c|c|}
\hline \multirow[b]{2}{*}{ Cover type } & \multirow[b]{2}{*}{ Treatment } & \multicolumn{8}{|c|}{ Rotation period (yr) } \\
\hline & & DNR-NSH & DNR-BL & USFS & PNIF & PIF & StL & Lake & $\mathrm{TNC}$ \\
\hline Aspen & clearcut & $53 / 73 \dagger$ & $53 / 73 \dagger$ & 64 & 140 & 40 & 55 & 53 & \\
\hline Black spruce & clearcut & 135 & 135 & 115 & 170 & 95 & 90 & 90 & \\
\hline Jack pine & clearcut & 70 & 70 & 70 & 60 & 40 & 70 & 70 & $75 \dagger$ \\
\hline Oak & shelterwood & 110 & 110 & 120 & 120 & 75 & 90 & 90 & $140 \dagger$ \\
\hline Red pine & clearcut & 120 & 120 & 120 & 100 & 80 & 120 & 120 & $140 \dagger$ \\
\hline Spruce-fir & clearcut & 75 & 90 & 80 & 100 & 75 & 70 & 70 & \\
\hline \multirow[t]{2}{*}{ Northern hardwoods } & uneven-aged & 18 & 25 & 20 & & & & & \\
\hline & $\begin{array}{l}\text { shelterwood } \\
\text { clearcut }\end{array}$ & & & & 170 & 75 & 120 & 120 & \\
\hline
\end{tabular}

Notes: If two rotation periods are listed for the same entry, a portion of that treatment is managed on an extended rotation. Key to abbreviations: DNR-NSH, DNR North Shore Highlands (Lake County); DNR-BL, DNR Border Lakes; USFS, United States Forest Service (Chippewa tribal lands); PNIF, private nonindustrial forest; PIF, private industrial forest; StL, St. Louis County (Itasca and Carlton Counties); Lake, Lake County; TNC, The Nature Conservancy. Entities in parentheses have no management documentation; these ownership types were grouped with the ownership type indicated.

$\dagger$ Managed on an extended rotation with reserves.

nitrogen $(\mathrm{Mg} / \mathrm{ha})$, soil water availability $(\mathrm{cm})$, and monthly climate data (mean and standard deviation of temperature and precipitation). The generalized ecosystem process model, PnET-II (Aber and Federer 1992) was used to calculate species-specific maximum ANPP $\left(\mathrm{ANPP}_{\max }\right)$ for each ecoregion. ANPP ${ }_{\max }$ is necessary to parameterize LANDIS-II biomass succession and can be estimated from a variety of sources including FIA data, gap models, and ecosystem process models (see Scheller and Mladenoff [2004] for a review). We chose to use PnET-II to calculate ANPP ${ }_{\max }$, rather than estimating it empirically, as PnET-II incorporates changes in climate into calculations of ANPP $\max$. PnET-II requires soil water holding capacity and monthly temperature, precipitation, and solar surface irradiance (SSI), as well as species parameters (i.e., percentage foliar nitrogen, and maximum leaf mass area; Table 1). To reflect climate variability, ANPP ${ }_{\text {max }}$ and $P_{\text {est }}$ were calculated at each five-year time step using mean monthly climate values plus the product of the standard deviation and a random number generated from a zero-centered normal distribution. Although soil water holding capacity was held constant, soil water availability varied with monthly precipitation values that are required inputs into calculations of $\mathrm{ANPP}_{\max }$ and $P_{\text {est }}$. Therefore, $\mathrm{ANPP}_{\text {max }}$ and $P_{\text {est }}$ reflect differences in the seasonality of precipitation under climate change.

\section{Management}

In the current management scenarios, management units were based on ownership (Fig. 2). Carlton, Itasca, and Lake Counties, and Chippewa tribal lands (Chippewa) lacked detailed management information and were grouped with larger management units based on known associations between management agencies, such as geographic proximity, agency type, and management approach (Table 2). Combined, these four ownership types comprise $<2.7 \%$ of the forested landscape and, similar to larger land management agencies, have based their management plans on goals and strategies outlined by the Minnesota Forest Resources Council (MFRC 2003).

For the major land management agencies (United States Forest Service, Minnesota Department of Natural Resources, St. Louis County, and Lake County) harvest prescriptions and rotation periods were based on ownership-specific management documentation (Table 2). Rotation estimates and patch size distributions for private nonindustrial forests (PNIF) and private industrial forests (PIF) were derived from Landsat change data (Wolter and White 2002) and surveys of timber harvest practices in Minnesota (Puettmann and Ek 1999; Table 2). Private nonindustrial forest was modeled using a mean patch size of five hectares (range 2.5-50 ha). A mean patch size of $\sim 25$ ha (range 2.5-250 ha) was used for all other ownership types.

There were four harvest prescriptions in the current management scenario: clearcut, clearcut with reserves, shelterwood, and group selection (Table 2). Clearcut prescriptions removed all species cohorts. Retention of mature white pine, white spruce, and white cedar occurred in extended rotation clearcuts. Shelterwood cuts consisted of two entries. In the first entry, $85 \%$ of cohorts were removed and a subset of cohorts in older age classes was retained. The second entry occurred $15-$ 20 years later, depending on the cover type, and the remainder of the original cohorts were removed. In group selection cuts, $20 \%$ of cohorts were removed and mature age classes were targeted; harvest activity occurred in small patches (5-20 ha) and was restricted to $30 \%$ of stand area.

In the restoration management scenario, management units were based on ecological land units (Fig. 3). Compositional targets for each ecological land unit were derived from estimates of historic forest composition (middle to late 1800s) based on an analysis of General Land Office (GLO) bearing tree data (White 2001a, b). In the restoration scenario, harvest activity was based on 
TABLE 3. Harvest rotation periods and patch size distributions in the restoration management scenario, under wind-based or firebased harvest prescriptions.

A) Wind-based harvest prescriptions:

\begin{tabular}{|c|c|c|c|c|}
\hline 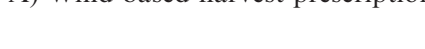 & & indthrow & Catas & windthrow \\
\hline Cover type & $\begin{array}{l}\text { Rotation } \\
\text { period (yr) }\end{array}$ & $\begin{array}{c}\text { Patch size range/ } \\
\text { mean (ha) } \dagger\end{array}$ & $\begin{array}{l}\text { Rotation } \\
\text { period }(\mathrm{yr})\end{array}$ & $\begin{array}{c}\text { Patch size range/ } \\
\text { mean (ha) } \dagger\end{array}$ \\
\hline Hardwood-conifer & 130 & $2.5-500 / 30$ & $>1000$ & $2.5-500 / 50$ \\
\hline Mesic white pine-red pine & $50-75$ & $2.5-2500 / 30$ & 1170 & $2.5-2500 / 100$ \\
\hline Dry-mesic white pine-red pine & $50-75$ & $2.5-2500 / 30$ & 610 & $2.5-2500 / 100$ \\
\hline Lowland conifer & 145 & $2.5-2500 / 30$ & 1500 & $2.5-2500 / 100$ \\
\hline Mesic birch-aspen-spruce-fir & 145 & $2.5-2500 / 30$ & 1500 & $2.5-2500 / 100$ \\
\hline Dry-mesic jack pine-black spruce & 145 & $2.5-2500 / 30$ & 1500 & $2.5-2500 / 100$ \\
\hline Boreal hardwood-conifer & 160 & $2.5-500 / 30$ & 960 & $2.5-500 / 50$ \\
\hline
\end{tabular}

B) Fire-based harvest prescriptions:

\begin{tabular}{lcccc} 
& \multicolumn{2}{c}{ Moderate surface fire } & & \multicolumn{2}{c}{ Stand-regenerating fire } \\
\cline { 2 - 3 } & $\begin{array}{c}\text { Rotation } \\
\text { period (yr) }\end{array}$ & $\begin{array}{c}\text { Patch size range/ } \\
\text { mean (ha) } \dagger\end{array}$ & $\begin{array}{c}\text { Rotation } \\
\text { period (yr) }\end{array}$ & $\begin{array}{c}\text { Patch size range/ } \\
\text { mean (ha) } \dagger\end{array}$ \\
\hline Hardwood-conifer & $160-300$ & $2.5-500 / 50$ & $>1000$ & $2.5-500 / 50$ \\
Mesic white pine-red pine & $50-75$ & $2.5-2500 / 50$ & 220 & $2.5-500 / 200$ \\
Dry-mesic white pine-red pine & $50-75$ & $2.5-2500 / 50$ & 170 & $2.5-500 / 200$ \\
Lowland conifer & 2000 & $2.5-2500 / 50$ & 2000 & $2.5-500 / 200$ \\
Mesic birch-aspen-spruce-fir & 260 & $2.5-2500 / 50$ & 220 & $2.5-500 / 200$ \\
Dry-mesic jack pine-black spruce & 75 & $2.5-2500 / 50$ & 220 & $2.5-500 / 200$ \\
Boreal hardwood-conifer & 160 & $2.5-500 / 50$ & 430 & $2.5-500 / 50$ \\
\hline
\end{tabular}

Note: The Methods: Management section describes the way in which harvest regimes based on these data were implemented in the restoration scenario.

$\dagger$ The range of patch sizes (ha) is listed first, followed by mean patch size (ha).

the frequency, severity, and size distribution of historic wind and fire regimes (Baker 1992). Disturbance patch size distributions were derived from historic air photo analysis (White and Host 2008). Windthrow rotation periods were estimated from the Minnesota Native Plant Community data (Minnesota DNR 2003; Table 3). Fire rotation periods for each ecological land unit were derived from a study of pre-European settlement disturbance patterns using General Land Office survey data (White and Host 2008; Table 3).

Harvest prescriptions in the restoration scenario were parameterized to four natural disturbance regimes: stand replacing fire, moderate surface fire, catastrophic windthrow, and moderate windthrow. Harvest prescriptions modeled after catastrophic windthrow removed all species cohorts and affected $60-90 \%$ of the stand. Patchy windthrow harvest prescriptions affected 70$90 \%$ of a stand and removed $50 \%$ of cohorts that were older than $60 \%$ of the species maximum longevity. In moderate fire prescriptions, harvest rules reflected species fire tolerance and cohort age. If the fire tolerance value of a species was less than 3 (intolerant of fire; classes range 1-5), all cohorts of that species were harvested. If fire tolerance was greater than 3 (fire tolerant), cohorts younger than $50 \%$ of maximum longevity were harvested. If fire tolerance was 3 (mid tolerant), cohorts were retained if they were older than $75 \%$ of the species maximum longevity. In the standreplacing fire prescription the stand was clearcut. Management activity on two preserves owned by The Nature Conservancy (TNC; Fig. 2) was the same in both active management scenarios. Every five years $\sim 50$ hectares $(1.3 \%$ of total holding) were planted with white pine, spruce, and cedar. Planting prescriptions targeted red pine and jack pine stands, with some underplanting in mature northern hardwoods.

\section{Wind and fire}

Although harvest is the dominant disturbance, the landscape is still influenced by wind and fire. The average rotation period for light-scale and moderatescale wind events (1-60\% canopy removal) and heavy windthrow ( $>60 \%$ canopy removal) is $\sim 116$ years and 1200 years, respectively, based on Minnesota Native Plant Community data (Minnesota DNR 2003). The total wind regime (including light, moderate, and heavy windthrow) had an average rotation period of $\sim 145$ years. The fire regime, derived from fire disturbance mapping from 24 aerial photography plots (1990-1998) distributed across the study region, had a mean return interval of $\sim 1500$ years (White and Host 2008), which reflects active fire suppression that has occurred across the landscape following European settlement. Wind and fire regimes were designated for the entire landscape and did not vary among scenarios.

\section{Data Analysis}

To assess within-scenario stochastic variation due to the random location and timing of disturbance events, each scenario was replicated five times with a different random number of seeds. For the nine scenarios considered, variance in forest composition among 
replicate runs was $<3 \%$ for all ecotypes. Therefore one replicate from each scenario was randomly selected for further analysis. We chose to use output in the final simulation year (2195) in our analysis as a 200-year period allows several iterations of harvest prescriptions. Given rotation periods for even-aged management of 40-140 years (Table 2), the cumulative effects of forest management activity across the landscape would not be fully realized if a shorter simulation period was considered.

We calculated total landscape dominance for seven forest cover types in the final simulation year (2195). Maps of dominant forest cover and maximum age were generated to assess spatial and temporal variation in the nine scenarios considered. Forest composition in each ecological land unit in the final simulation year (2195) was compared to restoration targets derived from estimates of historic forest composition (middle to late 1800s; White 2001a, b).

We combined forest cover maps at year 2195 to assess changes in forest composition among management and climate treatments. We mapped cover type changes for three broad forest types (hardwoods, pine, and aspen) for nine climate and management treatment combinations including differences among climate scenarios for each active management scenario (six scenario combinations) and differences among active management treatments for each climate scenario (three scenario combinations). For each cover type, we mapped four change categories: no change, loss, gain, and not present in either scenario. We also calculated the total proportion of the landscape in each change category for each forest type.

Differences in species biomass among scenarios and through time were evaluated using nonmetric multidimensional scaling (NMDS), with a relative Sørensen's distance metric (PC-ORD version 5.0; McCune and Mefford 1999). NMDS is a distance-based ordination technique that maximizes rank-order correlations between community dissimilarity and distance in ordination space (McCune and Grace 2002). Species biomass was selected as the response variable as it provides the most detailed output and thus captures the range of variation in species response to different climate and management treatments. Each observation in the data matrix represents average species biomass for a unique combination of simulation year (1995 or 2195), scenario, and ecotype (matrix dimensions of 70 observations $\times 24$ species). Treating each scenario and ecotype as a separate observation allowed us to assess the relative influence of management and climate treatments on community composition and to determine if treatment effects were consistent among ecotypes. Dissimilarity in the distribution of species biomass among observations is correlated with distance in ordination space. For example, ecotypes with similar species biomass are closer together, while those that are more dissimilar are farther apart. Species scores were plotted simulta- neously with observation scores. Species scores are calculated as the weighted average of observation scores and represent the central tendencies of each species with respect to the ordination axes.

\section{RESUlTS}

\section{Species composition}

Maps of forest type at the end of the 200-year simulation reveal differences in forest composition and spatial variation among the nine climate and management treatment combinations (Fig. 5). In our control climate scenarios the relative abundance of aspen was higher under current management, whereas later successional birch, spruce, and fir types were more prevalent across the landscape in the restoration scenario (Fig. 5). Regardless of management activity, forests dominated by white spruce, balsam fir, and paper birch were functionally extirpated from the landscape (percentage landscape dominance at or near zero) in all climate change scenarios (Fig. 6). Due to the loss of spruce, fir, and birch, the only consistent difference among active management scenarios under climate change was the relative abundance of aspen and white pine (Fig. 6). Black spruce, jack pine, red pine, and aspen suffered substantial or complete declines in scenarios without management but had unique responses to different management and climate change combinations. Black spruce, extirpated in both climate change scenarios with current management, was retained on the landscape in both restoration scenarios, albeit at low levels (Fig. 6). Jack pine abundance was higher in restoration treatments relative to current management treatments; abundance was similar in the control climate and low-emissions scenarios (Fig. 6). Red pine abundance did not differ among active management scenarios (current and restoration management treatments), but abundance was reduced by $52 \%$ in the low-emissions scenario as compared to the control scenario (Fig. 6). Jack pine and red pine were extirpated in high-emissions scenarios but the loss of jack pine on the landscape occurred 50 years earlier than red pine, reflecting the shorter longevity of jack pine. Aspen abundance was controlled primarily by management treatment. Active management retained aspen on the landscape in all climate scenarios, and the relative abundance of aspen was highest in current management scenarios irrespective of climate treatment (Fig. 6).

Maple species and white pine increased in climate change scenarios (Fig. 6). The expansion of sugar maple was most pronounced in climate change scenarios without harvest, whereas less shade-tolerant red maple increased more in climate change scenarios with active management (Fig. 6). The magnitude of red maple expansion under climate change was similar in both active management scenarios (Fig. 6), but the spatial distribution was more homogenous in current management treatments (Fig. 5). White pine abundance, highest in the restoration treatments, was also sensitive to 

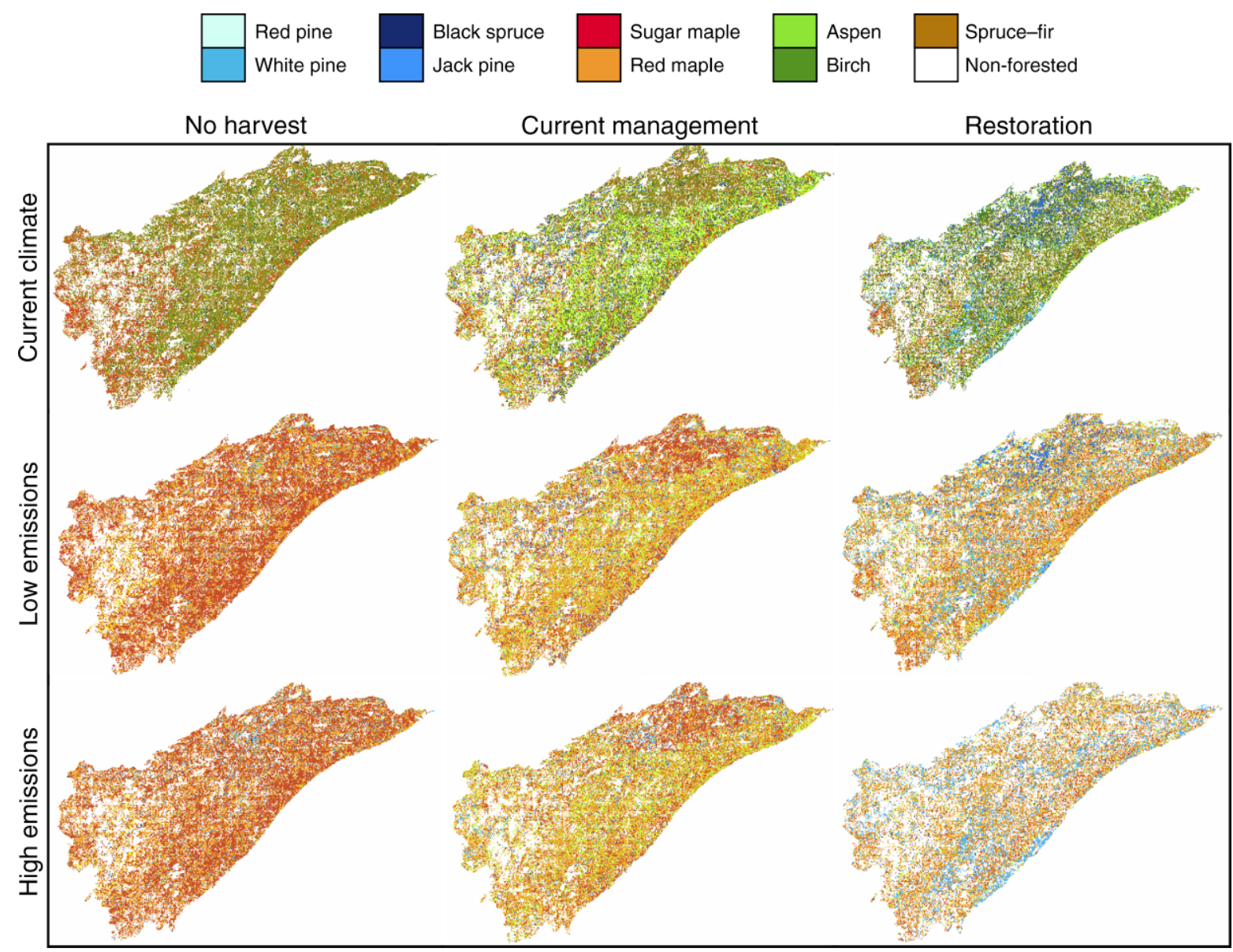

FIG. 5. Map of forest types at year 2195 for the nine scenarios. The red pine, white pine, jack pine, black spruce, and birch (Betula papyrifera) forest types are dominated by a single species. Other forest types are grouped by associated species. Aspen: Populus spp.; sugar maple, red maple: Acer saccharum, Acer rubrum, Betula alleghaniensis, Fraxinus spp., Tilia americana, Ulmus americana; Spruce-fir: Abies balsamea, Picea spp. Cells are reclassified to the forest type with the highest total biomass.

climate treatment; abundance was highest in the highemissions scenario and lowest in the control climate scenario.

Retention and planting of white pine in mesic and dry-mesic white pine-red pine, jack pine-black spruce, and mesic birch-aspen-spruce-fir ecotypes in the restoration management scenarios restricted red maple expansion under climate change (Fig. 7). Regions with limited planting and retention of white pine were more susceptible to red maple expansion as red maple is more shade tolerant and has a higher maximum dispersal distance than white pine (Table 1).

$$
\text { Age }
$$

The percentage of forest in older age classes was higher in all control climate scenarios relative to the initial condition and highest in the no-harvest scenario (Appendix A). Older age classes were more evenly distributed across the study region in restoration scenarios and noticeably aggregated in the Boundary
Waters Canoe Area (BWCA) in current management scenarios (Appendix B). The BWCA and private nonindustrial forest (PNIF) are the only two ownership types where the percentage of older stands was higher in the current management scenario relative to the restoration scenarios (Appendix A). There is no harvesting in the BWCA, and PNIF has the longest rotation periods of all active ownership types; combined, these two ownership categories cover $42 \%$ of the forested landscape (Fig. 2). The Nature Conservancy has a substantially higher proportion of age classes in the older categories compared to all other ownership types. For the remaining ownership types there were no substantial differences in age class distributions among active management scenarios (Appendix A).

\section{Restoration targets}

Species composition exhibited similar responses to climate and management treatments in five ecotypes: dry-mesic jack pine-black spruce, dry-mesic white 


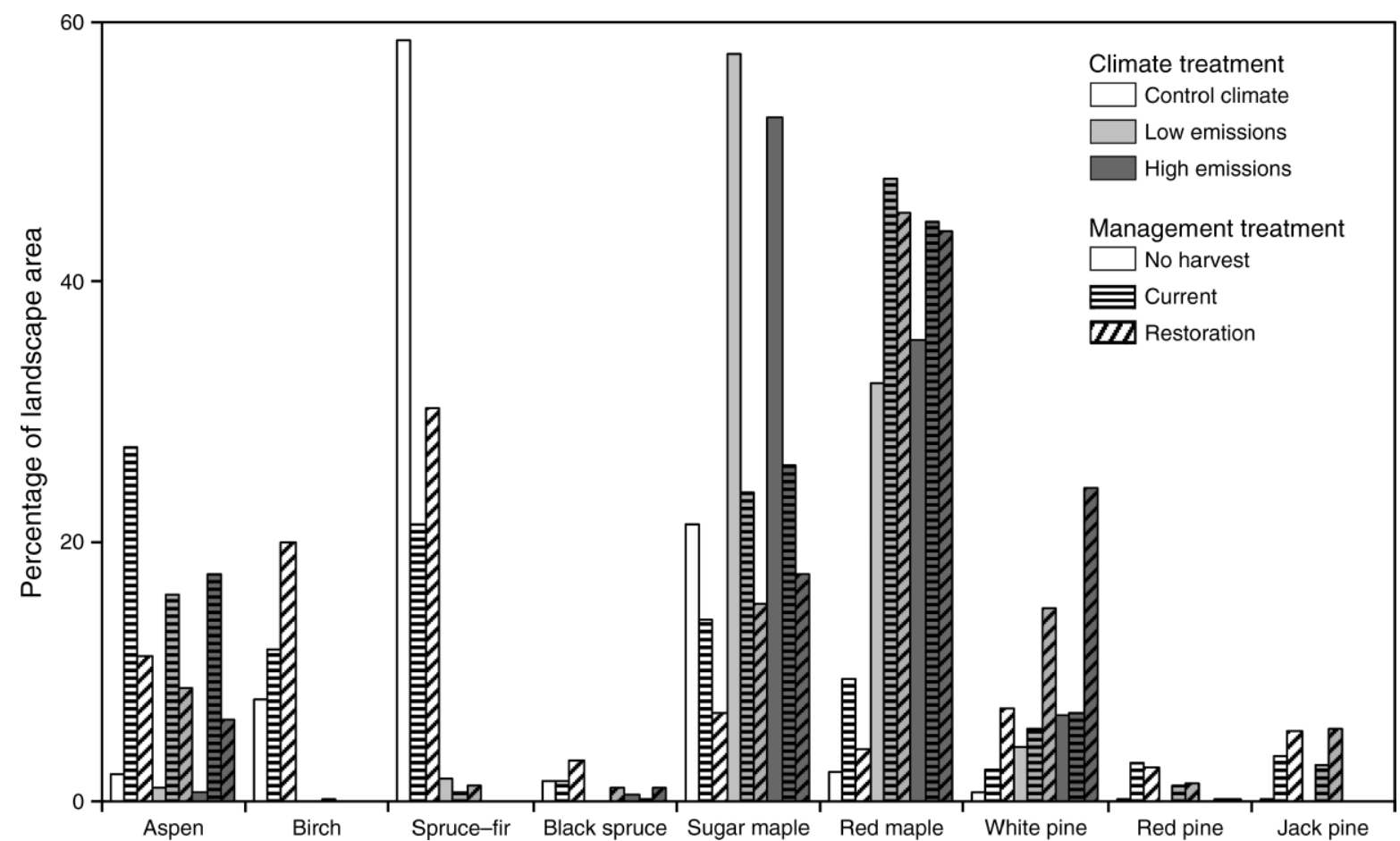

FIG. 6. Percentage of the landscape dominated by seven cover types at year 2195 for the nine scenarios. Open or shaded bars (white, light gray, dark gray) represent climate treatments, and patterned fills represent management treatment. Where there is no overlying pattern, there is no harvest. For example, light gray bars with horizontal stripes represent low emissions and current management. Non-forested sites were excluded from analysis.

pine-red pine, hardwood-conifer, mesic birch-aspenspruce-fir, and mesic white pine-red pine (Fig. 7). In control climate scenarios the relative abundance of aspen, birch, and spruce-fir in these five ecotypes was strongly tied to management activity and was closest to General Land Office (GLO)-derived targets in the restoration scenario (Fig. 7). In the control climate scenario with no management, aspen abundance decreased with a corresponding increase in spruce-fir abundance well above GLO-derived targets (Fig. 7). The trend was reversed in scenarios of current management where aspen increased substantially and spruce-fir abundance was well below GLO-derived targets (Fig. 7).

The extirpation of birch, spruce, and fir in climate change scenarios was associated with an increase in maple abundance. Without management, the abundance of sugar maple in these five land units was, on average, $82 \%$ and $77 \%$ higher than GLO-derived restoration targets in the low- and high-emissions scenarios, respectively (Fig. 7). The expansion of more southerly oak and hickory species was most evident in the boreal hardwood-conifer system in climate change scenarios without harvest (Fig. 7). Under climate change, oak species had a higher growth rate than maple species due to the southerly distribution of the boreal hardwoodconifer ecotype. Boreal hardwood-conifer was the only ecotype where northern hardwood abundance in climate change scenarios without harvest was lower than the control climate scenario (Fig. 7; 60\%, 43.16\%, and $53.70 \%$ above GLO levels in current climate, lowemissions, and high-emissions scenarios, respectively). In active management scenarios, the influx of oak and hickory was largely reduced with a corresponding increase in northern hardwoods dominated by red maple (Fig. 7).

\section{Cover type changes: climate treatments}

In active management scenarios, the dominant change between control climate and climate change scenarios was from aspen to other cover types (Table 4). This trend occurred consistently across the entire study region (Appendices $\mathrm{C}, \mathrm{D}$ ), and was higher in restoration management climate change combinations than in current management climate change combinations (Table 4). Declines in aspen under climate change were associated with increases in hardwood (Table 4). In current management, climate change combination shifts to hardwood were equivalent to shifts from aspen to other (Table 4). Conversion and retention of pine in restoration scenarios reduced transitions from aspen to hardwood (Appendices D, E).

\section{Cover type changes: active management treatments}

In the three management treatment combinations (difference between current and restoration management 


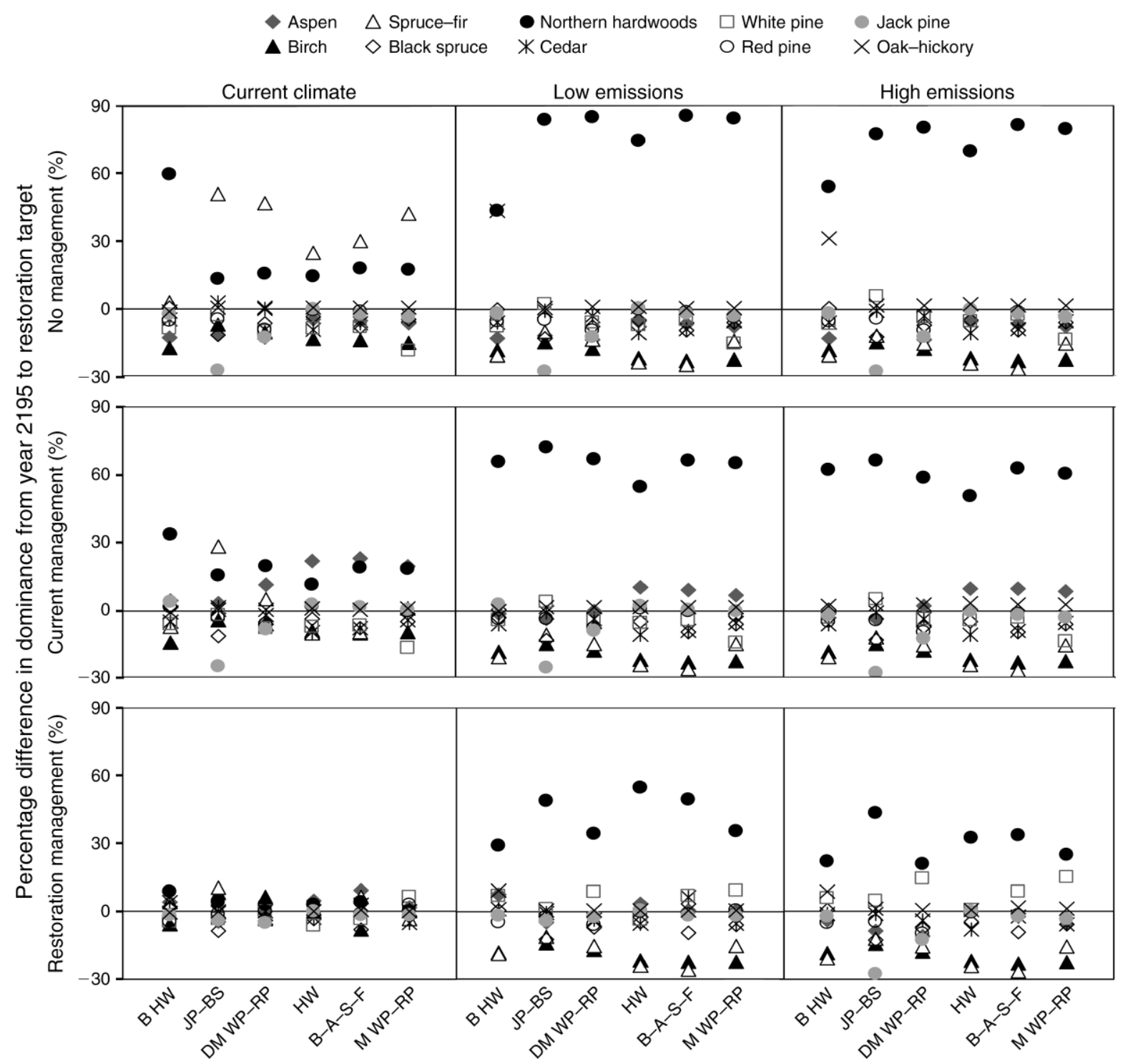

FIG. 7. Values are the difference between percentage of landscape dominance at year 2195 and restoration targets for each ecological land unit derived from estimates of historic forest composition (middle to late 1800s), based on an analysis of General Land Office (GLO) bearing-tree data (White 2001a, b). A value of zero indicates that restoration targets based on GLO data have been met for a particular cover type-ecological land unit combination. Abbreviations are: B HW, boreal hardwood-conifer; JP-BS, jack pine-black spruce; DM WP-RP, dry-mesic white pine-red pine; HW, hardwood-conifer; B-A-S-F, mesic birch-aspenspruce-fir; M WP-RP, mesic white pine-red pine. See Appendix F for associated data tables.

for the three climate scenarios), the dominant change in pine was conversion of other cover types to pine (Table $4)$. This trend reflects the lower amount of pine in current management scenarios (Fig. 6), and higher rates of pine retention and conversion in the restoration scenarios. The spatial distribution of pine conversion differs among the nine change combinations (Appendices $\mathrm{C}, \mathrm{E}$ ). Retention of pine occurs in the north and along Lake Superior in the current- to low-emissions restoration scenario combination (Appendix D). In the control- to high-emissions restoration scenario combi- nation, pine retention is similar along the lakeshore, but in the northern portion of the study region the dominant change is from pine to hardwoods due to the extirpation of jack and red pine (Appendix D).

\section{Conversion to non-forested}

In the high-emissions restoration treatment, $30 \%$ of the landscape was classified as non-forested. Less than $5 \%$ was classified as non-forested in all other scenarios. The extensive loss of forest in the high-emissions restoration scenario is due to the interaction of a period 
TABLE 4. Changes in forest composition among climate and management treatments for three cover classes: aspen, pine, and hardwood.

\begin{tabular}{|c|c|c|c|c|c|c|c|c|c|}
\hline \multirow[b]{3}{*}{ Cover class } & \multicolumn{9}{|c|}{ Changes in cover type ( $\%$ of area) } \\
\hline & \multicolumn{3}{|c|}{$\begin{array}{l}\text { Between climate } \\
\text { treatments with } \\
\text { current management }\end{array}$} & \multicolumn{3}{|c|}{$\begin{array}{l}\text { Between climate } \\
\text { treatments with } \\
\text { restoration management }\end{array}$} & \multicolumn{3}{|c|}{$\begin{array}{l}\text { Between current } \\
\text { management and } \\
\text { restoration management }\end{array}$} \\
\hline & $\mathrm{C}-\mathrm{LE}$ & $\mathrm{C}-\mathrm{HE}$ & LE-HE & $\mathrm{C}-\mathrm{LE}$ & $\mathrm{C}-\mathrm{HE}$ & LE-HE & $\mathrm{C}$ & LE & $\mathrm{HE}$ \\
\hline \multicolumn{10}{|l|}{ Aspen } \\
\hline No change & 11.82 & 11.54 & 4.85 & 6.83 & 3.55 & 0.88 & 40.56 & 1.82 & 0.97 \\
\hline Loss & 49.72 & 50.02 & 11.54 & 56.06 & 59.85 & 9.31 & 20.99 & 14.57 & 15.92 \\
\hline Gain & 4.55 & 4.93 & 11.63 & 3.10 & 1.59 & 4.36 & 21.92 & 8.05 & 4.23 \\
\hline Not present & 33.91 & 33.51 & 71.98 & 34.00 & 35.00 & 85.45 & 16.52 & 75.56 & 78.88 \\
\hline \multicolumn{10}{|l|}{ Pine } \\
\hline No change & 3.10 & 1.34 & 2.06 & 6.03 & 4.03 & 6.11 & 1.44 & 2.70 & 1.73 \\
\hline Loss & 5.63 & 7.39 & 7.48 & 8.95 & 11.07 & 15.03 & 7.28 & 6.83 & 5.15 \\
\hline Gain & 6.43 & 5.36 & 4.65 & 14.55 & 13.17 & 11.41 & 13.44 & 17.76 & 15.66 \\
\hline Not present & 84.85 & 85.91 & 85.82 & 70.47 & 71.73 & 67.45 & 77.83 & 72.71 & 77.47 \\
\hline \multicolumn{10}{|l|}{ Hardwood } \\
\hline No change & 18.57 & 16.83 & 50.06 & 8.37 & 6.46 & 30.53 & 4.99 & 41.40 & 30.39 \\
\hline Loss & 4.77 & 6.52 & 21.16 & 2.30 & 4.29 & 28.01 & 18.36 & 29.79 & 37.01 \\
\hline Gain & 52.58 & 48.88 & 15.69 & 48.65 & 37.20 & 13.92 & 5.60 & 15.27 & 13.74 \\
\hline Not present & 24.08 & 27.77 & 13.09 & 40.68 & 52.05 & 27.54 & 71.05 & 13.53 & 18.87 \\
\hline
\end{tabular}

Notes: Numbers reflect the percentage of the study area in each change class for a given scenario combination calculated on a cell-by-cell basis. For example, a cell classified as aspen in two treatments would be assigned "no change" in the aspen cover class and "not present" in both pine and hardwood cover classes. The first two sets of columns reflect the two climate scenarios being compared: C, control climate; LE, low emissions; HE, high emissions. The third set reflects changes in cover type between current and restoration management for the three climate scenarios. No change indicates that there is no difference in cover between the two scenarios; loss indicates change to another cover type; gain indicates change from another cover type; not present means that the cover type is not present in either scenario.

of low productivity and establishment for both maple species and constraints on establishment due to the large harvest patch sizes characteristic of the restoration scenario.

\section{Biomass}

A two-dimensional solution of nonmetric multidimensional scaling (NMDS) was selected as reductions in stress were relatively minor with additional dimensions. Results from the ordination reveal strong gradients in community composition in response to climate and management treatments. Axis 2 and axis 1 capture $63.2 \%$ and $27.7 \%$ of the variation in the original dissimilarity matrix, respectively (cumulative 90.9\%; Fig. 8). No-harvest scenarios had the lowest axis 1 scores and restoration scenarios had the highest axis 1 scores, suggesting that the first axis is associated with management activity. Axis 2 was associated with climatic tolerance. Ecotypes in the high-emissions and control climate scenarios had the lowest and highest axis 2 scores, respectively. Low axis 2 scores reflect increases in the biomass of temperate species (e.g., red maple, sugar maple) and higher scores are associated with an increase in biomass of northerly species such as paper birch, white spruce, and fir (Fig. 8). The retention of red pine, jack pine, and black spruce in the low-emissions restoration treatment increased axis 2 scores slightly (Fig. 8).

\section{Discussion}

The composition of the forest types in northeastern Minnesota will likely change dramatically under climate change. Results indicate that white spruce, balsam fir, and paper birch will be extirpated from the region irrespective of management activity. In the highemissions scenario, losses of black spruce, red pine, and jack pine also occurred. Mesic birch-aspen-sprucefir, and jack pine-black spruce systems will be substantially altered due to the loss of northerly species and the expansion of red and sugar maple. Current restoration targets developed for broad forest cover types will be illsuited for future forest conditions under climate change.

Forest management changed trajectories of climateinduced compositional shifts by increasing the prevalence of shade-intolerant species across the landscape. Scenarios without harvest encouraged transition to late successional cover types, and reduced forest type diversity across the landscape due to shade exclusion. As a consequence, without harvest activity the dominant compositional shifts under climate change were restricted to shade-tolerant species; spruce-fir was replaced by sugar maple-dominated northern hardwoods (Fig. 5). Shade-intolerant species such as aspen, jack pine, and red pine declined in scenarios without management in all climate scenarios (Fig. 6), similar to previous research (Scheller and Mladenoff 2005, Scheller et al. 2005). Climate-induced compositional shifts were lower in 


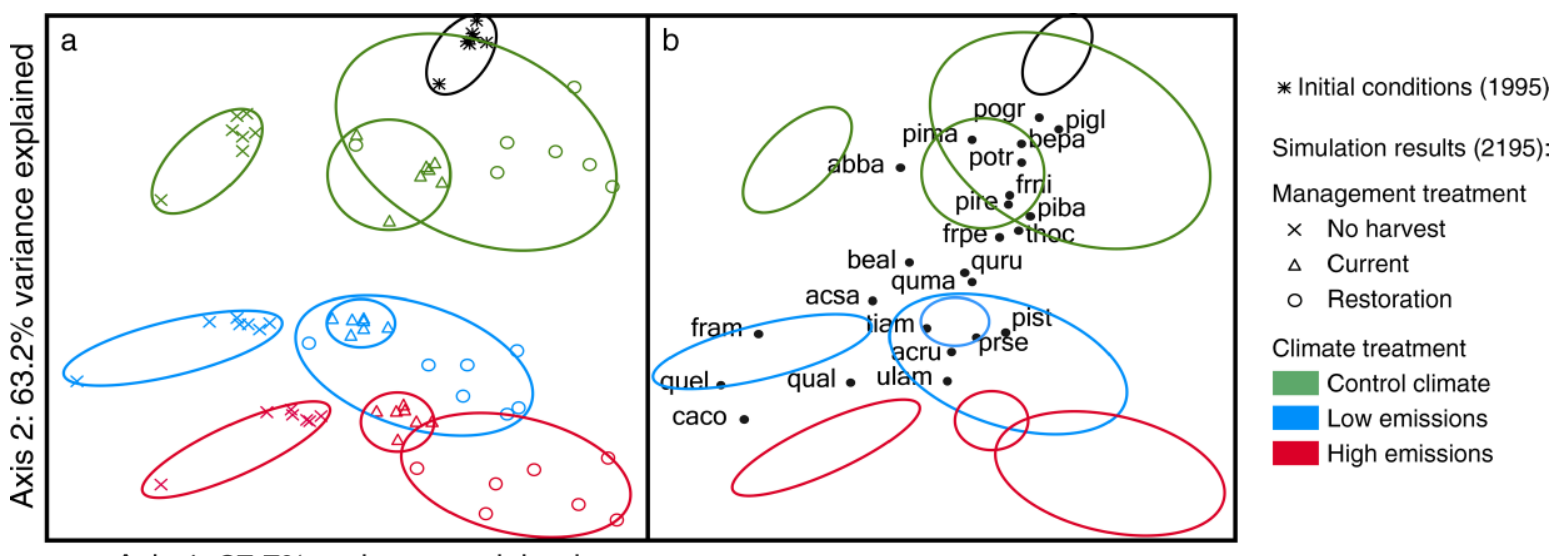

Axis $1: 27.7 \%$ variance explained

FIG. 8. Nonmetric multidimensional scaling ordination of mean species aboveground biomass by ecological land unit using a Sørenson dissimilarity matrix. (a) Distribution of mean species biomass for the seven ecological land units at years 1995 and 2195 . Colors reflect different climate scenarios, and symbols reflect different management treatments. The range of variation at year 1995 (initial condition) is approximated by a black-outlined ellipse. Color-outlined ellipses approximate the range of communities for climate and management scenarios at year 2195. The percentage of variance explained refers only to this panel. (b) Distribution of 24 tree species in ordination space. Distance reflects dissimilarity of relative biomass distribution across ecological land units. Species codes are the first two letters of the genus plus the first two letters of the species name (Table 1). Ellipses from panel (a) are overlaid on panel (b) as a reference. Axes are unitless.

scenarios with active management, as harvest activity provided suitable sites for the establishment of early successional species. The dominant compositional shift under climate change was influenced by harvest activity; less shade-tolerant red maple was more prevalent in active management scenarios, whereas sugar maple increased in no-management scenarios (Fig. 6).

Under current management assuming no change in climate, community composition diverged from the initial condition in all ecotypes (Fig. 8a). The divergence in community composition is associated with a decrease in aspen and an increase in spruce, fir, and birch cover types relative to the initial condition (Fig. 8b), consistent with previous research of alternative management regimes in the region (Mehta et al. 2004). The high percentage of aspen in the initial landscape is a relic of intensive management in the period following European settlement. The relative intensity of aspen management has declined under current management regimes. Climate treatments explained more variance in community composition than management treatments due to climate-induced declines in the biomass of northerly species (balsam fir, aspen, black spruce, and paper birch) and increases in sugar and red maple biomass (Fig. 8b). Although management treatments explained less of the total variance in community composition, within-treatment variance (i.e., divergence among ecotypes in a given treatment) was strongly tied to management activity (Fig. 8a). Differences in forest composition among ecological land units were the most pronounced in restoration management treatments (Fig. 8a). In contrast, in current management scenarios, ecotypes were more clustered in ordination space (Fig. 8a), reflecting homogenization of forest composition across ecotypes (Fig. 5). In the no-management scenario, forest composition was similar in most ecotypes, with the exception of the most southerly ecotype, boreal hardwood-conifer (Fig. 8a). Differences were associated with an increase in red and sugar maple biomass in boreal hardwood-conifer, whereas all other ecotypes were associated with an increase in fir biomass (Fig. 8b). In climate change scenarios, boreal hardwood-conifer still diverged from other ecotypes, but differences in community composition were associated with an increase in oak species, whereas the dominant transition was to maple in all other ecotypes (Fig. 8b).

Results from the restoration scenario under alternative emissions projections illustrate the benefits and limitations to implementing a range of natural variability (RNV)-based management approach (Millar and Woolfenden 1999). Widespread forest loss in the highemissions restoration scenario demonstrates the potential pitfalls of implementing a RNV-based management approach to a system that is not compositionally similar to the historic reference condition. For example, large clearcut prescriptions were used to mimic the historic fire regime in fire-dependent systems such as jack pineblack spruce, but prescriptions targeting fire-dependent pine species were detrimental to overall forest productivity when maple species expanded into these systems (Fig. 5). Our projections of forest loss in the highemissions restoration scenario may be overestimated, as we would expect less intensive management if productivity and establishment were substantially reduced under climate change. Furthermore, if extensive loss of forest occurred we would expect the expansion of forest 
species not simulated (e.g., shrubs) and/or transition to other systems such as grasslands in these regions.

The potential for active forest management to mitigate climate-induced shifts in forest composition is most evident in the low-emissions scenario. In the highemissions scenario, the forest management options considered here become less effective at influencing the rate of forest transition. But even under the lowemissions scenario with purposeful, ecologically based forest management, a trend toward homogenization of forest conditions occurs (Fig. 5). Following the framework set out in Millar et al. [2007], an adaptive approach to forest management, which includes resilience, resistance, and response options, may be the most effective strategy, given the uncertain impacts of climate change.

The magnitude of compositional shifts projected suggests a rather limited capacity for resilience of this system (Ludwig et al. 1997, Chapin et al. 2007, Millar et al. 2007) but an RNV-based management approach could promote resistance to climate-induced expansion of hardwoods dominated by red and sugar maple. In mesic and dry-mesic white pine-red pine and jack pineblack spruce ecotypes, retention and conversion to white pine may be the most effective means of restricting red maple expansion. Treatments to maintain or increase the abundance of jack pine and red pine could minimize regional species loss, particularly if targeted in the northern portion of the study region. However, this may not be a feasible long-term strategy, particularly if climate changes as projected in the high-emissions scenario. Planting these species in mixtures with white pine may minimize the potential for climate-induced declines in productivity, or dieback. In mesic birchaspen-spruce-fir, short-rotation clearcuts could forestall the loss of economically valuable cover types such as aspen, and no-harvest management would promote sugar maple, reducing the expansion of red maple (Abrams 1998).

Our simulations include four species that are currently uncommon or not present in the study area, but are likely to expand under climate change: white ash, northern pin oak, white oak, and bitternut hickory. Growth rates and establishment probabilities of these four species were comparable to other species in scenarios of climate change. Expansion of oak and hickory was very limited, suggesting that dispersal limitation and disturbance may restrict northern migration rates despite the expansion of suitable niche space for these species under climate change predicted in previous studies (Iverson and Prasad 2001, Prasad et al. 2006). However, our ability to parameterize the timing and magnitude of northward migration was limited. Future work should focus on alternative management strategies such as assisted migration of more southerly oak species. This would allow us to determine the sensitivity of our predictions to alternative assumptions of the timing and magnitude of northern migration and assess the potential influence of southerly species on compositional shifts under climate change.

\section{Uncertainty}

The biggest sources of uncertainty in any climate change simulation are the emissions and climate projections. At the time of parameterization, GCM model output was only available at the monthly time step necessary for LANDIS-II initialization for the A2 and $\mathrm{B} 2$ emissions scenarios. Given these constraints, the A2 and B2 SRES emissions scenarios were selected to capture the range of possible emissions scenarios. Our projections under the low-emissions scenarios may considerably underestimate the magnitude of change as $\mathrm{CO}_{2}$ emissions in the past few decades are more consistent with high-emissions scenarios (Rahmstorf et al. 2007). Future work should incorporate more emission scenarios (using updated GCMs) recently made available as part of the IPCC Fourth Assessment Report (AR4; IPCC 2007). Furthermore, our estimates of forest change may be conservative as mean climate values were held constant after the first 100 years in climate change scenarios.

Our use of maximum growing degree days to delimit species southern range limits is conservative (Loehle 2000). If extant northern species remain for a longer period than our projections, the expansion of maple species could be delayed. Variation in recruitment success under climate change is another source of uncertainty. Recent work suggests that recruitment success of species near their southern range limit is higher under warmer springs (Ibáñez et al. 2007). Our limited understanding of seed dispersal and current and historic tree species migration rates (Clark et al. 1998, McLachlan et al. 2005) are other potential sources of uncertainty, both for extant species and as related to the northern expansion of southerly species.

Our simulations are limited by the data necessary to parameterize many important processes. For example, the effects of $\mathrm{CO}_{2}$ fertilization on ANPP and water use efficiency are poorly understood and were not included in our simulations. Incorporation of feedbacks among overstory composition, disturbance, and soil carbon and nitrogen would significantly improve our ability to model successional dynamics. Our simulations also did not consider the potential confounding effects of land use change, host-specific pathogens (Moorcroft et al. 2006), insect defoliation (Bale et al. 2002), herbivory (Post and Pederson 2008), and modified disturbance regimes including the frequency and intensity of fire (Dale et al. 2001). Finally, the capacity for species adaptation and acclimation to future climates is a significant source of uncertainty (Jump and Penuelas 2005). As strict model validation against empirical data (Rastetter 1996) is not possible for long-term simulations, our results should not be interpreted as concrete 
predictions. Rather, they highlight the relative influence of climate and disturbance processes on regional trends of species composition.

\section{Conclusions}

Of all the possible changes to forests in northeastern Minnesota, the expansion of systems dominated by maple may prove to be the most dramatic. Although alternative harvest practices can influence the direction of compositional shifts, the magnitude of change has the potential to render obsolete restoration targets developed for broad forest cover types. An RNV-based management approach promotes a diversity of species and conditions across the landscape and could promote resistance to climate-induced changes in forest composition. But, efforts to reverse climate-induced shifts in forest composition would likely be prohibitively expensive and could result in undesirable consequences such as a loss in productivity. Given the uncertainty associated with climate change, an iterative approach to management in which conservation targets and alternative management techniques are tested and refined progressively may be the most effective strategy. Restoration targets and management strategies intentionally developed for uncertainty ("indeterministic," sensu, Millar et al. 2007), including increasing species redundancy and buffers by introducing species over a range of environments and promoting diverse age classes and species mixtures to increase landscape asynchrony may be the most effective means of ensuring continued productivity (Millar et al. 2007). Furthermore, facilitation of species transitions may be the most effective means of maintaining ecosystems if not at the same location. For example, maple species may be lost from more southern locales. Collaboration among border states to plan for their expansion into Minnesota would ensure that they are not regionally extirpated. Planning for an uncertain future will require on the ground monitoring of species establishment, growth, and mortality rates across a range of environments, combined with cross-border discussions and coordinated management efforts. In addition to guiding management decisions, monitoring efforts would provide information to elucidate some of the key uncertainties in predicting species response to future climate change, including recruitment success, migration rates, and the potential for adaptation and acclimation of extant forest types.

\section{ACKNOWLEDGMENTS}

We thank Peter Wolter (University of Wisconsin-Madison) for providing the Landsat forest classification and stand age coverages. We also thank E. Kruger, P. Townsend, and an anonymous reviewer, whose suggestions improved earlier versions of this manuscript. This project was funded by $\mathrm{RJ} /$ Kose and The Cox Family Fund for Science and Research. Additional support for C. Ravenscroft was provided by the Department of Forest and Wildlife Ecology, University of Wisconsin-Madison.

\section{Literature Cited}

Aber, J., N. Christensen, I. Fernandez, J. Franklin, L. Hidinger, M. Hunter, J. MacMahon, D. Mladenoff, J. Pastor, D. Perry, R. Slangen, and H. van Miegroet. 2000. Applying ecological principles to management of the U.S. National Forests. Issues in Ecology 6. Ecological Society of America, Washington, D.C., USA.

Aber, J. D., and C. A. Federer. 1992. A generalized, lumpedparameter model of photosynthesis, evapotranspiration and net primary production in temperate and boreal forest ecosystems. Oecologia 92:463-474.

Abrams, M. D. 1998. The red maple paradox. BioScience 48: $355-364$

Allen, C. D., and D. D. Breshears. 1998. Drought-induced shift of a forest-woodland ecotone: rapid landscape response to climate variation. Proceedings of the National Academy of Sciences (USA) 95:14839-14842.

Bachelet, D., R. P. Neilson, J. M. Lenihan, and R. J. Drapek. 2001. Climate change effects on vegetation distribution and carbon budget in the United States. Ecosystems 4:164-185.

Baker, F. S. 1949. A revised tolerance table. Journal of Forestry 47:179-181.

Baker, W. L. 1992. The landscape ecology of large disturbances in the design and management of nature reserves. Landscape Ecology 7:181-194.

Baker, W. L. 1994. Restoration of landscape structure altered by fire suppression. Conservation Biology 8:763-769.

Bale, J. S., et al. 2002. Herbivory in global climate change research: direct effects of rising temperature on insect herbivores. Global Change Biology 8:1-16.

Bergeron, Y., and B. Harvey. 1997. Basing silviculture on natural ecosystem dynamics: an approach applied to the southern boreal mixedwood forest of Quebec. Forest Ecology and Management 92:235-242.

Blinn, C. R., and E. R. Buckner. 1989. Normal foliar nutrient levels in North American forest trees: a summary. Station Bulletin 590-1989. Minnesota Agricultural Experiment Station, University of Minnesota, St. Paul, Minnesota, USA.

Bolstad, P. V., K. J. Davis, J. Martin, B. D. Cook, and W. Wang. 2004. Component and whole-system respiration fluxes in northern deciduous forests. Tree Physiology 24:493-504.

Bolster, K. L. 1996. Determination of carbon fraction and nitrogen concentration in tree foliage by near infrared reflectance: a comparison of statistical methods. Canadian Journal of Forest Research 26:590-600.

Bradshaw, W. E., and C. M. Holzapfel. 2006. Evolutionary response to rapid climate change. Science 312:1477-1478.

Broennimann, O., U. A. Treier, H. Müller-Schärer, W. Thuiller, A. T. Peterson, and A. Guisan. 2007. Evidence of climatic niche shift during biological invasion. Ecology Letters 10:701-709.

Chapin, F. S., K. Danell, T. Elmqvist, C. Folke, and N. Fresco. 2007. Managing climate change impacts to enhance the resilience and sustainability of Fennoscandian forests. Ambio 36:528-533.

Clark, J. S., et al. 1998. Reid's paradox of rapid plant migration. Bioscience 48:13-24.

Collingham, Y. C., and B. Huntley. 2000. Impacts of habitat fragmentation and patch size upon migration rates. Ecological Applications 10:131-144.

Dale, V. H., et al. 2001. Climate change and forest disturbances. BioScience 51:723-734.

Daly, C., R. P. Neilson, and D. L. Phillips. 1994. A statisticaltopographic model for mapping climatological precipitation over mountainous terrain. Journal of Applied Meteorology 33:140-158.

Davis, M. B. 1989. Lags in vegetation response to greenhouse warming. Climatic Change 15:75-82. 
Davis, M. B., and R. G. Shaw. 2001. Range shifts and adaptive responses to quaternary climate change. Science 292:673679.

Fownes, J. H. 1985. Water use and primary production of Wisconsin hardwood forests. Dissertation. University of Wisconsin, Madison, Wisconsin, USA.

Franklin, J. F., et al. 1991. Effects of global climate change on forests in northwestern North America. Northwest Environmental Journal 7:233-254.

Frelich, L. 1999. Range of natural variability in forest structure for the Northern Superior Uplands. Minnesota Forest Resources Council, Minnesota Department of Natural Resources, St. Paul, Minnesota, USA.

Frelich, L. 2000. Natural Range of Variability estimates for forest vegetation growth stages of Minnesota's Drift and Lake Plains. Minnesota Forest Resources Council, Minnesota Department of Natural Resources, St. Paul, Minnesota, USA.

Friedman, S. K., and P. B. Reich. 2005. Regional legacies of logging: departure from presettlement forest conditions in northern Minnesota. Ecological Applications 15:726-744.

Friedman, S. K., P. B. Reich, and L. E. Frelich. 2001. Multiple scale composition and spatial distribution patterns of the north-eastern Minnesota presettlement forest. Journal of Ecology 89:538-554.

Green, D. S. 1998. Interrelation of leaf structure and function among deciduous broad-leaved and evergreen needle-leaved trees in southern Wisconsin. Dissertation. University of Wisconsin, Madison, Wisconsin, USA.

Green, D. S., J. E. Erickson, and E. L. Kruger. 2003. Foliar morphology and canopy nitrogen as predictors of light-use efficiency in terrestrial vegetation. Agricultural and Forest Meteorology 115:165-173.

Hall, F. G., D. B. Botkin, D. E. Strebel, K. D. Woods, and S. J. Goetz. 1991. Large-scale patterns of forest succession as determined by remote sensing. Ecology 72:628-640.

Hampe, A. 2004. Bioclimate envelope models: what they detect and what they hide. Global Ecology and Biogeography 13: 469-471.

Hampe, A., and R. J. Petit. 2005. Conserving biodiversity under climate change: the rear edge matters. Ecology Letters 8:461467.

Hannah, L., G. F. Midgley, and D. Millar. 2002. Climate change-integrated conservation strategies. Global Ecology and Biogeography 11:485-495.

He, H. S., D. J. Mladenoff, and J. Boeder. 1999a. An objectoriented forest landscape model and its representation of tree species. Ecological Modelling 119:1-19.

He, H. S., D. J. Mladenoff, and T. R. Crow. 1999b. Linking an ecosystem model and a landscape model to study forest species response to climate warming. Ecological Modelling 114:213-233.

He, H. S., D. J. Mladenoff, V. C. Radeloff, and T. R. Crow. 1998. Integration of GIS data and classified satellite imagery for regional forest assessment. Ecological Applications 8: 1072-1083.

Heinselman, M. L. 1973. Fire in the virgin forests of the Boundary Waters Canoe Area, Minnesota. Quaternary Research 3:329-382.

Heinselman, M. L. 1981. Fire and succession in the conifer forests of northern North America. Pages 374-406 in D. C. West, H. H. Shugart, and D. B. Botkin, editors. Forest succession: concepts and application. Springer-Verlag, New York, New York, USA.

Heinselman, M. L. 1996. The Boundary Waters Wilderness Ecosystem. University of Minnesota Press, Minneapolis, Minnesota, USA.

Hobbs, R. J., et al. 2006. Novel ecosystems: theoretical and management aspects of the new ecological world order. Global Ecology and Biogeography 15:1-7.
Ibáñez, I., J. S. Clark, S. LaDeau, and J. Hille Ris Lambers. 2007. Exploiting temporal variability to understand tree recruitment response to climate change. Ecological Monographs 77:163-177.

IPCC. 2007. Climate Change 2007: The physical science basis. Contribution of Working Group 1 to the Fourth Assessment Report of the Intergovernmental Panel on Climate Change. IPCC secretariat, World Meteorological Organization, Geneva, Switzerland.

Iverson, L. R., and A. M. Prasad. 1998. Predicting abundance of 80 tree species following climate change in the eastern United States. Ecological Monographs 68:465-485.

Iverson, L. R., and A. M. Prasad. 2001. Potential changes in tree species richness and forest community types following climate change. Ecosystems 4:186-199.

Jenkins, J. C., D. W. Kicklighter, and J. D. Aber. 2000. Regional impacts of climate change and elevated carbon dioxide on forest productivity. Pages 383-424 in R. A. Mickler, R. A. Birdsey, and J. L. Hom, editors. Responses of northern forests to environmental change. Springer-Verlag, New York, New York, USA.

Jogiste, K., T. Kuuluvainen, and A. Kangur. 2007. Disturbances at multiple scales as the basis of forest ecosystem restoration and management. Forest Ecology and Management 250:1-2.

Johnson, D. W., and P. S. Curtis. 2001. Effects of forest management on soil $\mathrm{C}$ and $\mathrm{N}$ storage: meta analysis. Forest Ecology and Management 140:227-238.

Jump, A. S., and J. Penuelas. 2005. Running to stand still: adaptation and the response of plants to rapid climate change. Ecology Letters 8:1010-1020.

Jurik, T. W. 1986. Temporal and spatial patterns of specific leaf weight in successional northern hardwood tree species. American Journal of Botany 73:1083-1092.

Kuuluvainen, T. 2002. Disturbance dynamics in boreal forests: defining the ecological basis of restoration and management of biodiversity. Silva Fennica 36:5-11.

Landres, P. B., P. Morgan, and F. J. Swanson. 1999. Overview of the use of natural variability concepts in managing ecological systems. Ecological Applications 9:1179-1188.

Lee, T. D., P. B. Reich, and P. V. Bolstad. 2005. Acclimation of leaf respiration to temperature is rapid and related to specific leaf area, soluble sugars and leaf nitrogen across three temperate deciduous tree species. Functional Ecology 19: 640-647.

Little, E. L. 1971. Atlas of United States trees. Volume 1, conifers and important hardwoods. U.S. Department of Agriculture Miscellaneous Publication 1146.

Loehle, C. 2000. Forest ecotone response to climate change: sensitivity to temperature response functional forms. Canadian Journal of Forest Research 30:1632-1645.

Ludwig, D., B. Walker, and C. S. Holling. 1997. Sustainability, stability, and resilience. Conservation Ecology 1:1-26.

Malanson, G. P., and D. M. Cairns. 1997. Effects of dispersal, population delays, and forest fragmentation on tree migration rates. Plant Ecology 131:67-79.

Martin, M. E., and J. D. Aber. 1997. High spectral resolution remote sensing of forest canopy lignin, nitrogen, and ecosystem processes. Ecological Applications 7:431-443.

McCune, B., and J. B. Grace. 2002. Analysis of ecological communities. MjM Software Design, Gleneden Beach, Oregon, USA.

McCune, B., and M. J. Mefford. 1999. PC-ORD: multivariate analysis of ecological data. Version 5.0. MjM Software, Gleneden Beach, Oregon, USA.

McLachlan, J. S., J. S. Clark, and P. S. Manos. 2005. Molecular indicators of tree migration capacity under rapid climate change. Ecology 86:2088-2098.

Mehta, S., L. E. Frelich, M. T. Jones, and J. Manolis. 2004. Examining the effects of alternative management strategies 
on landscape-scale forest patterns in northeastern Minnesota using LANDIS. Ecological Modelling 180:73-87.

MFRC. 2003. Recommended desired outcomes, goals and strategies, northeast landscape region. Minnesota Forest Resources Council, St. Paul, Minnesota, USA.

Millar, C. I., N. L. Stephenson, and S. L. Stephens. 2007. Climate change and forests of the future: managing in the face of uncertainty. Ecological Applications 17:2145-2151.

Millar, C. I., and W. B. Woolfenden. 1999. The role of climate change in interpreting historical variability. Ecological Applications 9:1207-1216.

Minnesota DNR. 2003. Field guide to the native plant communities of Minnesota: the Laurentian Mixed Forest Province. Ecological Land Classification Program, Minnesota County Biological Survey, and Natural Heritage and Nongame Research Program. Minnesota Department of Natural Resources, St. Paul, Minnesota, USA.

Mladenoff, D. J., and H. S. He. 1999. Design, behavior and applications of LANDIS, an object-oriented model of forest landscape disturbance and succession. Pages 124-162 in D. J. Mladenoff and W. L. Baker, editors. Advances in spatial modeling of forest landscape change: approaches and applications. Cambridge University Press, Cambridge, UK.

Mladenoff, D. J., G. E. Host, J. Boeder, and T. R. Crow. 1996. LANDIS: a spatial model of forest landscape disturbance, succession, and management.. Pages 175-180 in M. F. Goodchild, L. T. Steyaert, B. O. Parks, C. Johnston, and S. Glendining, editors. GIS and environmental modeling: progress and research issues. GIS World Books, Fort Collins, Colorado, USA.

Moorcroft, P. R., S. W. Pacala, and M. A. Lewis. 2006. Potential role of natural enemies during tree range expansions following climate change. Journal of Theoretical Biology 241:601-616.

Murphy, H. T., and J. Lovett-Doust. 2007. Accounting for regional niche variation in habitat suitability models. Oikos 116:99-110.

Neilson, R. P. 1993. Transient ecotone response to climatic change: some conceptual and modeling approaches. Ecological Applications 3:385-395.

Neilson, R. P. 1995. A model for predicting continental-scale vegetation distribution and water balance. Ecological Applications 5:362-385.

Noble, I. R. 1993. A model of the responses of ecotones to climate change. Ecological Applications 3:396-403.

Noss, R. F. 2001. Beyond Kyoto: forest management in a time of rapid climate change. Conservation Biology 15:578-590.

Overpeck, J. T., D. Rind, and R. Goldberg. 1990. Climateinduced change in forest disturbance and vegetation. Nature 343:51-53.

Pastor, J., and W. M. Post. 1988. Response of northern forests to $\mathrm{CO}_{2}$-induced climate change. Nature 334:55-58.

Pitelka, L. F. 1997. Plant migration and climate change. American Scientist 85:464-473.

Post, E., and C. Pederson. 2008. Opposing plant community responses to warming with and without herbivores. Proceedings of the National Academy of Sciences (USA) 105:1235312358.

Prasad, A. M., and L. R. Iverson. 2003. Little's range and FIA importance value database for 135 eastern U.S. tree species. Northeastern Research Station, USDA Forest Service, Delaware, Ohio, USA. 〈http://www.fs.fed.us/ne/delaware/ 4153/global/littlefia/index.html $\rangle$

Prasad, A. M., L. R. Iverson, and A. Liaw. 2006. Newer classification and regression tree techniques: bagging and random forests for ecological prediction. Ecosystems 9:181199.

Puettmann, K., and A. Ek. 1999. Status and trends of silvicultural practices in Minnesota. Northern Journal of Applied Forestry 16:203-210.
Rahmstorf, S., A. Cazenave, J. A. Church, J. E. Hansen, R. F. Keeling, D. E. Parker, and R. C. J. Somerville. 2007. Recent climate observations compared to projections. Science 316 : 709-709.

Rastetter, E. B. 1996. Validating models of ecosystem response to global change. BioScience 46:190-198.

Reich, P. B., B. D. Kloeppel, D. S. Ellsworth, and M. B. Walters. 1995. Different photosynthesis-nitrogen relations in deciduous hardwood and evergreen coniferous tree species. Oecologia 104:24-30.

Royer, D. L., P. Wild, D. A. Janesko, E. A. Kowalski, and D. L. Dilcher. 2005. Correlations of digital leaf physiognomy to climatic and ecological variables: potential proxies for the fossil record. American Journal of Botany 92:1141-1151.

Saxe, H., M. G. R. Cannell, B. Johnsen, M. G. Ryan, and G. Vourlitis. 2001. Tree and forest functioning in response to global warming. New Phytologist 149:369-399.

Saxton, K., W. Rawls, J. Romberger, and R. Papendick. 1986. Estimating generalized soil-water characteristics from texture. Soil Science Society of America Journal 50:1031-1036.

Scheller, R. M., J. Domingo, B. Sturtevant, J. Williams, A. Rudy, E. Gustafson, and D. Mladenoff. 2007. Design, development, and application of LANDIS-II, a spatial landscape simulation model with flexible temporal and spatial resolution. Ecological Modelling 201:409-419.

Scheller, R. M., and D. J. Mladenoff. 2004. A forest growth and biomass module for a landscape simulation model, LANDIS: design, validation, and application. Ecological Modelling 180:211-229.

Scheller, R. M., and D. J. Mladenoff. 2005. A spatially interactive simulation of climate change, harvesting, wind, and tree species migration and projected changes to forest composition and biomass in northern Wisconsin, USA. Global Change Biology 11:307-321.

Scheller, R. M., and D. J. Mladenoff. 2008. Simulated effects of climate change, fragmentation, and inter-specific competition on tree species migration in northern Wisconsin, USA. Climate Research 36:191-202.

Scheller, R. M., D. J. Mladenoff, T. R. Crow, and T. A. Sickley. 2005. Simulating the effects of fire reintroduction versus continued fire absence on forest composition and landscape structure in the Boundary Waters Canoe Area, northern Minnesota, USA. Ecosystems 8:396-411.

Schulte, L. A., D. J. Mladenoff, T. R. Crow, L. C. Merrick, and D. T. Cleland. 2007. Homogenization of northern U.S. Great Lakes forests due to land use. Landscape Ecology 22:10891103.

Schwartz, M. W., L. R. Iverson, A. M. Prasad, S. N. Matthews, and R. J. O'Connor. 2006. Predicting extinctions as a result of climate change. Ecology 87:1611-1615.

Smith, M. L., and M. E. Martin. 2001. A plot-based method for rapid estimation of forest canopy chemistry. Canadian Journal of Forest Research. 31:549-555.

Spittlehouse, D. L. 2005. Integrating climate change adaptation into forest management. Forestry Chronicle 81:91-95.

Spittlehouse, D. L., and R. B. Stewart. 2003. Adaptation to climate change in forest management. BC Journal of Ecosystems and Management 4(1):7-17.

STATSGO. 1994. State soil geographic database. Data use information. Report number 1492. U.S. Department of Agriculture National Cartography and GIS Center, Fort Worth, Texas, USA.

Swetnam, T. W., C. D. Allen, and J. L. Betancourt. 1999. Applied historical ecology: using the past to manage for the future. Ecological Applications 9:1189-1206.

Sykes, M. T., and I. C. Prentice. 1996. Climate change, tree species distributions and forest dynamics: a case study in the mixed conifer/northern hardwoods zone of northern Europe. Climatic Change 34:1573-1480.

Ward, B. C., D. J. Mladenoff, and R. M. Scheller. 2004. Simulating landscape-level effects of constraints to public 
forest regeneration harvests due to adjacent residential development in northern Wisconsin. Forest Science 51:616632.

White, M. A. 2001a. Growth stage summaries for ecosystems of the Northern Superior Uplands. Minnesota Forest Resources Council, Minnesota Department of Natural Resources, St. Paul, Minnesota, USA.

White, M. A. 2001b. Growth stage summaries for ecosystems of the Drift and Lake Plains section. Minnesota Forest Resources Council, Minnesota Department of Natural Resources, St. Paul, Minnesota, USA.

White, M. A., and G. E. Host. 2000. Mapping range of natural variation in ecosystems classes for the Northern Superior Uplands: draft map and analytical methods. NRRI Technical Report NRRI/TR-2000/39. Natural Resources Research Institute, University of Minnesota, Duluth, Minnesota, USA.
White, M. A., and G. E. Host. 2008. Forest disturbance frequency and patch structure from pre-European settlement to present in the Mixed Forest Province of Minnesota, USA. Canadian Journal of Forest Research 38:2212-2226.

Williams, J. W., and S. T. Jackson. 2007. Novel climates, noanalog communities, and ecological surprises. Frontiers in Ecology and the Environment 5:475-482.

With, K. A. 2004. Assessing the risk of invasive spread in fragmented landscapes. Risk Analysis 24:803-815.

Wolter, P. T., D. J. Mladenoff, G. E. Host, and T. R. Crow. 1995. Improved forest classification in the Northern Lake States using multi-temporal Landsat imagery. Photogrammetric Engineering and Remote Sensing 61:1129-1143.

Wolter, P. T., and M. A. White. 2002. Recent forest cover type transitions and landscape structural changes in northeast Minnesota, USA. Landscape Ecology 17:133-155.

\section{APPENDIX A}

Maximum species age by ownership type at year 1995 (initial conditions) and 2195 for the three control climate management scenarios (Ecological Archives A020-009-A1).

\section{APPENDIX B}

Maximum species age at year 2195 for the nine scenarios (Ecological Archives A020-009-A2).

\section{APPENDIX C}

Changes in forest cover due to climate treatment in the current management scenario (Ecological Archives A020-009-A3).

\section{APPENDIX D}

Changes in forest cover due to climate treatment in the restoration management scenario (Ecological Archives A020-009-A4).

\section{APPENDIX E}

Differences due to active management for the three climate scenarios (Ecological Archives A020-009-A5).

\section{APPENDIX F}

Data tables to accompany Fig. 7 (Ecological Archives A020-009-A6). 